\title{
KRONIKARSKIE DZIEŁO HISTORYCZNE JAKO PROJEKT NOWEJ PRZYSZŁOŚCI IZRAELA
}

Po okresie intensywnych badań nad deuteronomistycznym dziełem historycznym uwaga biblistów i historyków starożytnego Izraela coraz częściej koncentruje się na Pierwszej i Drugiej Księdze Kronik oraz Księdze Ezdrasza i Nehemiasza, określanych jako kronikarskie dzieło historyczne. Wyraża się w nim odmienne podejście do przeszłości Izraela niż to, które dominuje w zbiorze obejmującym Księgi Jozuego i Sędziów, a także Pierwszą i Drugą Księgę Samuela oraz Pierwszą i Drugą Księgę Królewską. Największa, chociaż nie dość doceniana, różnica polega na wyraźniejszym ukierunkowaniu retrospekcji Kronikarza ku kształtowaniu przyszłości, której rysy są nowe w porównaniu z sytuacją sprzed wygnania babilońskiego. Był to przejaw głębokiej transformacji religii Izraela skutkującej wyłonieniem się jej nowej formy: judaizmu.

\section{Kronikarskie dzieło historyczne}

Dyskusje wokół historycznej wiarygodności Ksiąg Kronik, traktowanych jako pierwsza część kronikarskiego dzieła historycznego, mają dawny rodowód, sięgający narodzin współczesnej krytyki biblijnej. ${ }^{1}$ Po wahaniach i mniej czy bardziej nieśmiałych sugestiach dyskusje nabrały tempa w XIX w. Kierunek nadał zwłaszcza J. Wellhausen

S. J a p h e t, The Historical Reliability of Chronicles. The History of the Problem and Its Place in Biblical Research, Journal for the Study of the Old Testament 33/1985, s. 83-107; toż w: J. C h e r y 1 E x u m (red.), The Historical Books, The Biblical Seminar 40, Sheffield 1997, s. 258-281. 
twierdząc, że Pierwsza i Druga Księga Kronik to midrasz napisany w okresie tzw. pisarzy, na skutek czego w autonomicznym dziele mamy do czynienia z mieszaniną dawnych i nowych elementów. ${ }^{2}$ Kilkadziesiąt lat później T. Willi wyraził przekonanie, że obie księgi stanowią rezultat egzegezy, bądź komentarz, do starszych źródeł, głównie Dtr. W nowych okolicznościach i wychodząc naprzeciw nowym potrzebom, jakie pojawiły się w okresie perskim, dokonano ich reinterpretacji, zatem chodzi nie tyle o poszerzenie czy kontynuację, ile wykład i wyjaśnienie jako rezultat zamierzonego studium. ${ }^{3}$ Z kolei R. J. Coggings ${ }^{4}$ i P. R. Ackroyd ${ }^{5}$ postrzegają Pierwszą i Drugą Księgę Kronik jako teologię, czyli spójną religijną syntezę dziejów dokonaną na potrzeby żydowskiej wspólnoty powygnaniowej. Dla odmiany I. Kalimi jest zdania, że księgi te to historia, co ma potwierdzać fakt, iż Septuaginta umieściła je właśnie wśród ksiąg historycznych. ${ }^{6}$ Podobnie twierdzi K.G. Hoglund, która podkreśla, że retrospekcja historyczna została dokonana nie w duchu semickiego deuteronomistycznego dzieła historycznego, lecz po linii historiografii hellenistycznej, zapożyczając z niej modele i metody. ${ }^{7}$ Natomiast G. N. Knoppers jest zdania, że obie Księgi Kronik to „powtórna/ponowna Biblia”, której celem jest dostarczenie spójnej interpretacji starszego tekstu biblijnego. Dlatego zamiast dociekania jej rodzaju literackiego, należy skoncentrować wysiłki na odczytaniu

2 J. W e $11 \mathrm{~h}$ a u s e n, Prolegomena zur Geschichte Israels, Berlin $1883^{2}$.

3 T. W i 11 i, The Chronik als Auslegung, FRLANT 106, Göttingen 1972.

4 R. J. C o g g i n s, The First and Second Books of Chronicles, Cambridge 1976.

5 P. R. A c k r o y d, The Chronicler in His Age, JSOTSupp 101, Sheffield 1991.

${ }^{6}$ I. K a 1 i m i, Historia, historiografia a wiarygodność historyczna. Księa Kronik na tle starożytnego piśmiennictwa bliskowschodniego i grecko-rzymskiego, Poznańskie Studia Teologiczne 23/2009, s. 7-25; t e n ż e, Starożytny historyk izraelski. Studium o Kronikarzu, jego epoce, miejscu działalności i dziele, Kraków 2016 (zob. rec. w: Collectanea Theologica 87/2017/ nr 2, s. 243-247).

7 K. G. H o g $1 \mathrm{u} \mathrm{n}$ d, The Chronicler as Historian: A Comparativist Perspective, w: M. P. G r a h a $\mathrm{m}$ i in. (red.), The Chronicler as Historian, Sheffield 1997, s. 19-29. 
zamysłu Kronikarza. ${ }^{8}$ W jego dziele należy upatrywać wczesną reinterpretację Pierwszej Księgi Samuela - Drugiej Księgi Królewskiej, w gruncie rzeczy zgodną z duchem Dtr i kapłańską tradycją rozumienia i objaśniania Prawa. ${ }^{9}$ Różnice i odmienne rozłożenie akcentów w deuteronomicznej i kronikarskiej retrospekcji przeszłości wynikają z faktu, że druga ma za sobą nie tylko dramat zburzenia świątyni, lecz i definitywnie zakończone doświadczenie przymusowych deportacji oraz powrót z wygnania. ${ }^{10}$

Co się tyczy relacji Pierwszej i Drugiej Księgi Kronik z Księgami Ezdrasza i Nehemiasza, wbrew rozmaitym domniemaniom i sugestiom wciąż aktualny pozostaje pogląd, który w pierwszej połowie XIX w. wyraził L. Zunz:" ${ }^{11}$ jest to dzieło Kronikarza - jednego anonimowego autora bądź grupy autorów. Ta ocena pozostaje ważna mimo dużych różnic w języku i teologii obydwu części. Po pierwsze, w Księgach Kronik dominuje nacisk na Dawida i przymierze z Dawidem, nieobecny w Księgach Ezdrasza i Nehemiasza; po drugie, tradycja o Wyjściu obecna w Księgach Ezdrasza i Nehemiasza, jest nieobecna w Księgach Kronik; po trzecie, odrzucenie małżeństw mieszanych u Ezdrasza i Nehemiasza jest nie do pogodzenia z narracją w Księgach Kronik; po czwarte, motyw natychmiastowej kary Bożej obecny w obu Księgach Kronik jest nieobecny u Ezdrasza i Nehemiasza. Jednak wskazane różnice nie przesądzają o całkowicie odmiennym pochodzeniu Pierwszej i Drugiej Księgi Kronik oraz Ksiąg Ezdrasza i Nehemiasza. Jedna i druga część eksponuje po dwóch bohaterów: w obu Księgach Kronik to Dawid i Salomon, a w części drugiej dwie tytułowe postacie, czyli Ezdrasz i Nehemiasz.

8 G. N. K n o p p e r s, I Chronicles 1-9, The Anchor Bible 12, New York 2003; t e $\mathrm{n}$ ż e, I Chronicles 10-29, The Anchor Bible 12A, New York 2004.

9 B. D. G i f fo n e, According to Which "Law of Moses"? Cult Centralization in Samuel, Kings and Chronicles, Vetus Testamentum 67/2017, s. 432-447.

10 E. H. M e r i 11, The Theology of the "Chronicles": What Difference Does It Make? Journal of the Evangelical Theological Society 59/2016, s. 691-700.

${ }^{11}$ L. Z u n z, Dibre hajamim oder die Bücher der Chronik, w: t e n ż e, Die Gottesdienstlichen Vorträge der Juden historisch entwickelt, Frankfurt 1832, s. 20-22. 
Narracja drugiej części zakłada kontynuację z poprzednią (2Krn 36,22-23 i Ezd 1,1-3a). Łącznikiem jest również dobitne podkreślenie dominacji perskiej $(2 \mathrm{Krn} 36,20)$ oraz wspólny nacisk na świątynię i kult. Nie bez znaczenia jest i to, że obie części kronikarskiego dzieła historycznego były w liturgii synagogalnej czytane łącznie.

Nie ma pełnej zgody odnośnie do datowania kronikarskiego dzieła historycznego, istnieje natomiast zgoda, że jest ono unikatowe w całej Biblii Hebrajskiej. Jego specyfika staje się widoczna zwłaszcza w kontekście innych pism z okresu po wygnaniu babilońskim. Różni się bowiem od opracowanych i zredagowanych wtedy ksiąg prorockich, w których utrwalono znacznie starsze tradycje (Iz, Ez, Jl, Jo), a także od ksiąg zawierających orędzie proroków powygnaniowych (Ag, Za, Ma) oraz od zredagowanego po wygnaniu dokumentu P i obszernego zbioru Pism (Prz, Hi, Est, Rt, Pnp). Pierwsza Księga Kronik - Księga Nehemiasza to jedyne dzieło historiograficzne mające analogie w księgach deuterokanonicznych oraz pismach autorów greckich i łacińskich, świadczące o udanym spotkaniu kultury semickiej z kulturą starożytnego Zachodu. Powstało (terminus ante quem) przed II w. przed Chr., ponieważ weszło w skład Septuaginty, a inne jej księgi (np. Syr 47,8-10) zakładają jego znajomość. Dane wewnętrzne wskazują na koniec V w. przed Chr.; ostatni wzmiankowany potomek Dawida to Ananiasz urodzony ok. 445 r. przed Chr., a ostatnie imię przytoczone w Ne 12,11 to kapłan Iaddua, prawdopodobnie Iadduda II urodzony ok. 420 r. przed Chr. To samo sugeruje cytat Za 4,10 w 2Krn 16,9 oraz takie anachronizmy, jak darejki w 1Krn 29,7 wnoszone na rzecz świątyni jerozolimskiej czy wzmianka o „starej mierze" poczyniona w $2 \mathrm{Krn} 3,3$.

Najbardziej wiarygodne i uzasadnione jest datowanie kronikarskiego dzieła historycznego na przełom V i IV w. przed Chr., kiedy sprawy świątyni jerozolimskiej i sprawowanego w niej kultu były bardzo aktualne i ważne. Jego autor to anonimowy pisarz(e) z wczesnego okresu Drugiej Świątyni, który, mając na względzie radykalne przemiany społeczne, polityczne i religijne, podjął, analogicznie jak 
autor apokryficznej Księgi Jubileuszy, próbę uzgodnienia różnych tradycji teologicznych. ${ }^{12}$

\section{Retrospekcja przeszłości w Pierwszej i Drugiej Księdze Kronik}

Pierwszą Księgę Kronik otwiera zbiór rodowodów i wykazów (1Krn 1-9), nie zawsze ze sobą spójnych, pochodzących z różnych źródeł, przede wszystkim z Tory/Pięcioksięgu i deuteronomicznego dzieła historycznego. ${ }^{13}$ Jego celem jest ukazanie związku historii Izraela jako ludu Bożego wybrania z początkami świata i człowieka oraz początkami jego wiary w jedynego Boga i tożsamości wspólnoty religijnej opartej na wierze w Boga. ${ }^{14}$ Dominuje podkreślanie znaczenia i roli potomstwa Dawida jako trwałego potwierdzenia i znaku wierności Boga Izraela. Klarowna kompozycja tego fragmentu to skutek starannie określonego zamysłu. Oto poszczególne człony:

1. Od Adama do patriarchów Izraela (1,1-27);

2. Patriarchowie Izraela i przodkowie jego sąsiadów $(1,28-2,2)$;

3. Potomstwo Judy $(2,3-4,23)$;

4. Rodowody plemienne $(4,24-9,44)$.

12 J. T i ñ o, An Elaboration of Some Theological Issues of Second Temple Judaism in Chronicles and Jubilees, Communio Viatorum 59/2017, s. 25-47.

13 H. L a n g k a m m e r, Kwestia źródet w 1 i 2 Księdze Kronik i technika ich opracowania, w: W. C h r o s t o w s k i (red.), „Pan moim świattem”. Księga pamiątkowa dla Księdza Profesora Jerzego Chmiela w65. rocznicę urodzin, Ad Multos Annos 4, Warszawa 2000, s. 214-218; S. S c h w e i t z e r, The Genealogies of 1 Chronicles 1-9: Purposes, Forms, and the Utopian Identity of Israel, w: P. S. E v a n s, T. F. W i 11 i a m s (red.), Chronicling the Chronicler: The Book of Chronicles and Early Second Temple Historiography, Winona Lake (IN) 2013, s. 9-17; K. B o d n e r, Reading the Lists: Several Recent Studies of the Chronicles Genealogies, w: tamże, s. 29-41.

14 M. M ü n n i c h, O pokusach uświęcania historii, albo o nadgorliwości biblijnego Kronikarza stów parę, w: U. B o r k o w s k a (red.), Peregrinatio ad veritatem. Studia ofiarowane profesor Aleksandrze Witkowskiej OSU z okazji 40-lecia pracy naukowej, Prace Wydziału Historyczno-Filologicznego 111, Lublin 2004, s. 315-324; H. L a n g k a m m e r, Historia teologizowana. Fenomen interpretacji historii w 1-2Krn, Quaestiones Selectae 17(2010) nr 26, s. 87-106. 
Co się tyczy pierwszego członu, widać stopniowe, lecz bardzo konsekwentne, ukierunkowanie i zawężanie spojrzenia. U samych początków (ww. 1-4) jest Adam, pierwszy człowiek, co potwierdza „kanoniczny” status Księgi Rodzaju otwierającej zbiór Tory. Wiernie odtworzono treść Rdz 5,1-32, a niewielkie różnice pochodzą od późniejszych kopistów. Rodowód zawiera imiona jedynie męskich potomków bez dodatków obecnych w Księdze Rodzaju. Następnie (ww. 5-23) rodowód, oparty na Rdz 10,2-29, akcentując, że wszystkie narody ziemi pochodzą od Noego (,nowy Adam”), wylicza trzy grupy: potomkowie Jafeta $(1,5-7)$, Chama (1,8-16) i Sema (1,17-23). Nie podaje się wszystkich potomków, lecz tylko wybranych, często pierworodnych, ale nie zawsze. Natomiast ww. 24-27 koncentrują się na potomkach Sema jako protoplastach Izraela. Nawiązując do Rdz 11,10-26, zaniechano wyliczania przodków innych ludów semickich, skupiając się na potomkach Abrahama i przypominając, że Abram to Abraham (Rdz 17,5), od którego rozpoczyna się czas Izraela. Ważna jest inkluzja obecna w pierwszym członie: dziesięć pokoleń od Adama do Noego (ww. 1-4) oraz dziesięć pokoleń od Sema, syna Noego, do Abrahama (ww. 24-27).

Kolejne trzy człony potwierdzają dalsze zawężanie spojrzenia. Po lakonicznym nawiązaniu do patriarchów Izraela i przodków ich sąsiadów $(1,28-2,2)$, uwaga koncentruje się na wyliczeniu potomstwa Judy $(2,3-4,23)$, zaś rodowody plemienne $(4,24-9,44)$ dwukrotnie (7,6-12 oraz 8,1-40) wysuwają na plan pierwszy plemię Beniamina. Pod koniec pierwszej części zamysł Kronikarza jest wyraźnie widoczny: chodzi mu o absolutnie uprzywilejowane umiejscowienie pochodzenia oraz roli dwóch pokoleń, a mianowicie Judy i Beniamina, w przeszłości Izraela i dziejach ludzkości. Mimo że wykazy plemion Izraela znajdują się w innych fragmentach Biblii, jednak w tym przypadku rzuca się w oczy ich wyjątkowa kolejność, dająca priorytet Judzie i Beniaminowi kosztem pozostałych. ${ }^{15}$

15 E. V i e z e 1, The Order of the Tribes in 1Chron 2-8 according to the Commentary on Chronicles Attributed to Sa'adia Gaon'as Student, Biblische Notizen 174/2017, s. 91-105. 
Dalsza zawartość Pierwszej i Drugiej Księgi Kronik potwierdza i ukierunkowuje zamysł wykazów zamieszczonych w części pierwszej. W centrum zainteresowania znajduje się świątynia i kult, co uzasadnia absolutnie wyjątkowe wyeksponowanie dwóch postaci z dziejów przedwygnaniowego Izraela. Pierwsza, o której opowiada 1Krn 10-29, to Dawid, przedstawiony jako twórca liturgii, któremu Izraelici zawdzięczają psalmy. Druga, o której mowa w 2Krl 1-9, to Salomon jako budowniczy świątyni jerozolimskiej. O ile w Pierwszej i Drugiej Księdze Samuela oraz w Pierwszej i Drugiej Księdze Królewskiej na pierwszy plan wybijają sie czterej bohaterowie: Samuel Saul - Dawid - Salomon, o tyle w obu Księgach Kronik tylko dwaj: Dawid i Salomon. Kronikarza nie interesuje ich osoba ani polityka, lecz zasługi, jakie położyli wobec kultu i świątyni. Dlatego wszyscy władcy z rodu Dawida wzmiankowani w 2Krl 10-36 są chwaleni, albo ganieni, za swój stosunek wobec świątyni i kultu, przy czym na pierwszym planie są dwaj szczególnie zasłużeni królowie, którym poświęcono więcej miejsca niż pozostałym, a mianowicie Ezechiaszowi (2Krn 29-32) i Jozjaszowi (2Krn 34-35).

Sednem zamysłu, który ożywia Pierwszą i Drugą Księgę Kronik, stanowiącego zasadniczy punkt odniesienia, jest podkreślenie tożsamości Izraela oraz roli monarchii i świątyni jerozolimskiej w warunkach, jakie zaistniały po powrocie z wygnania. Chodzi o to, czy poszczególni władcy z okresu przed wygnaniem sprostali, bądź nie, odpowiedzialności i zobowiązaniom wynikającym z wybrania Izraela i jego przymierza z Bogiem. ${ }^{16} \mathrm{Na}$ tym tle lepiej uwidacznia się pytanie, czy w nowej rzeczywistości Kronikarz widzi możliwość odnowienia dynastii Dawidowej i jej powrotu do władzy. Odpowiedź jest negatywna, o czym przesądza kilka czynników. ${ }^{17}$ Po pierwsze, dominuje nacisk na lud/naród, a nie króla; po drugie, mocno został

16 G. N. K n o p p e r s, Judah, Levi, David, Solomon, Jerusalem, and the Temple: Election and Covenant in Chronicles, w: N. M a c D o n a $1 \mathrm{~d}$ (red.), Covenant and Election in Exilic and Post-Exilic Judaism, Tübingen 2015, s. 139-168.

17 M. J. L y n c h, The Davidic Covenant and Institutional Integration in Chronicles, w: tamie, s. 169-188. 
podkreślony kult sprawowany w świątyni, a nie władza polityczna; po trzecie, pojawia się wątek, że Izraelem rządzą obcy władcy; po czwarte, istnieje przekonanie, że sprawowanie władzy nad Izraelem, czyli królowanie, należy do Boga, a nie ludzkiego władcy; po piąte, linia Dawidowa kończy się wzmianką o niej w ostatnim wersecie Drugiej Księgi Kronik; po szóste, kult ma być kontynuowany bez względu na brak instytucji monarchii. Taka retrospekcja nie tylko odtwarza przeszłość, lecz również kształtuje przyszłość, wybierając z przeszłości to, co należy podjąć, zachować i rozwijać, oraz piętnując albo pomijając to, co zostało uznane za niegodne kontynuowania.

Rodowody Kronikarza nawiązujące do rodowodów zamieszczonych w zbiorze Tory odróżnia to, że nie poprzestają na określeniu relacji względem innych ludów i narodów, lecz wyraźnie się od nich odcinają. Jego podejście i sposób potraktowania tworzywa przejętego z deuteronomistycznego dzieła historycznego idzie jeszcze dalej. Aczkolwiek jest ono podstawowym źródłem dla Kronikarza, jednak niemal całkowicie przemilcza znaczenie królestwa Izraela istniejącego od śmierci Salomona do zagłady Samarii i wspomina o nim tylko wtedy, gdy wymaga tego konieczność. Nie poprzestaje zatem na separacji od bliższych i dalszych sąsiadów Izraela, lecz posuwa się znacznie dalej, wybierając separację w obrębie samego Izraela. W Księgach Ezdrasza i Nehemiasza pojęcie „Izrael” odnosi się wyłącznie do plemienia Judy i Beniamina, a nawet zostało jeszcze bardziej zawężone i odnosi się jedynie do repatriantów, którzy powrócili z wygnania babilońskiego.

Na osobną uwagę zasługuje stosunek Kronikarza do wygnania babilońskiego, które w zasadzie zostało przemilczane, lub swoiście zracjonalizowane. ${ }^{18}$ Przekonujące uzasadnienie tej sytuacji podał E. Ben Zvi. ${ }^{19}$ W okresie, gdy Kronikarz opracowywał swoje dzieło

18 D. F. M u r r a y, Dynasty, People, and the Future: The Message of Chronicles, Journal for the Study of the Old Testament 58/1993, s. 71-97; toż w: J. C h e r y 1 E x u m, The Historical Books, s. 286-290.

19 E. B e n Z v i, Towards a Sense of Balance: Remembering the Catastrophe of Monarchic Judah/(Ideological) Israel and Exile through Reading Chronicles in 
oraz kształtował się kanon ksiąg świętych i wyłaniała instytucja synagogi, rosła także świadomość, że to, co zostało utrwalone na piśmie i przez wspólnotę przyjęte, będzie systematycznie czytane i rozważane, a więc również zapamiętane. Im częściej będzie czytane, tym bardziej zostanie zapamiętane, rzutując na zbiorową świadomość. Kronikarskie dzieło historyczne pomija dramatyczny i upokarzający okres wygnania, sugerując, że w gruncie rzeczy nie miał wpływu na ciągłość pamięci i tożsamości Izraela sprzed wygnania i po nim. W taki sposób relatywnie niewielka społeczność judzkich repatriantów zawłaszczyła całą przeszłość Izraela sprzed wygnania babilońskiego, a dokonawszy jej radykalnej reinterpretacji kładzie podwaliny pod tożsamość żydowską.

\section{„Przeciwnicy Judy i Beniamina” z wizytą u Zorobabela} $($ Ezd 4,1-2)

Dwa pierwsze rozdziały Księgi Ezdrasza przedstawiają powrót z wygnania jako masowe przedsięwzięcie, a nie rozłożony w czasie proces powracania mniejszych grup repatriantów. Elementy historii i pamięci zostały przetworzone w jedną spójną historię, która służyła legitymizacji działalności Ezdrasza. Po dłuższej, a więc swoiście „pełniejszej” wersji dekretu Cyrusa (1,1-4) niż umieszczona na końcu Drugiej Księgi Kronik, przedstawiającej „,dobrego” Cyrusa w opozycji do ,złego" Nabonida, następuje wyidealizowany, a więc propagandowy, opis reakcji przywódców i sąsiadów (1,5-8), opowiadając o ich entuzjastycznej i niezwykle przychylnej odpowiedzi na dekret władcy perskiego. Nawiązanie do zwrotu sprzętów świątynnych (1,9-11) ukazuje szczególne miejsce Judy i Beniamina oraz kapłanów i lewitów, przychylność pogańskich sąsiadów oraz ciągłość kultu (terminologia z Wj 11,2; 12,35-36). Dominuje spojrzenie ideologiczne oparte na nawiązaniu do przeszłości (tradycja Wyjścia) i obietnicy danej prorokowi Jeremiaszowi (Jr 29,10). Powrót z wygnania jest

Late Yehud; w: P. S. Ev a n s, T. F. W i 11 i a m s (red.), Chronicling the Chronicler, s. $247-265$ 
przedstawiany nie tyle w kategoriach politycznych, społecznych czy ekonomicznych, ile religijnych i duchowych.

Rozdział drugi Księgi Ezdrasza zawiera wykaz powracających/ repatriantów. Prowadzi ich (ww. 1-2) dwunastu przywódców, na których czele stoi Zorobabel (= Szeszbassar?) i Jozue, wnuk arcykapłana Serajasza $(2 \mathrm{Krl} 25,18.21$; $1 \mathrm{Krn} 5,40-41)$, ale nie są to już przedstawiciele dwunastu plemion Izraela. W wersetach 3-20 podkreśla się ich pokrewieństwo i więzi rodzinne, a ww. 21-35 przenoszą nacisk z pokrewieństwa na miejscowości pochodzenia (ziomkowie). Chodzi odzyskanie tej samej ziemi przez prawowitych właścicieli, ale jest to jedynie kraj Judy i Beniamina. Co więcej, ,ubodzy kraju” (2Krl 5,12), czyli ci, którzy uniknęli deportacji do Babilonii, są postrzegani jako osoby pozbawione tytułu własności. Wyszczególniając kapłanów (ww. 36-39), lewitów (ww. 40-42) i sług świątynnych (ww. 43-58) wyznacza się (ww. 59-63) granice przynależności tych, którzy wprawdzie mieli związki z wygnańcami, ale nie mogli udowodnić swego prawowitego pochodzenia, wykluczając ich od pełnienia funkcji kapłańskich. Podając całkowitą liczbę powracających (ww. 64-67) i chwaląc szczodrość przywódców, którzy dobrowolnie przekazywali datki (ww. 68-69) mówi się o osiedleniu się w Jerozolimie i jej okolicach, kładąc nacisk na rzeczywistość, a nie tylko symbolikę powrotu (w. 70).

W pierwszym i drugim rozdziale Księgi Ezdrasza nie ma opisu powrotu, jak to jest w Księdze Wyjścia - Księdze Powtórzonego Prawa. ${ }^{20}$ Dominuje nacisk na wznowienie kultu, zarówno od strony sprzętów, jak i osób, co świadczy o kontynuacji z sytuacją religijną sprzed wygnania. Dopuszcza się możliwość włączenia niektórych „obcych”, wyznaczając im jednak właściwe dla nich miejsce w nowej wspólnocie. Pojawia się motyw obcego władcy, lecz rola Cyrusa jest diametralnie inna niż Nabuchodonozora, a wcześniej (anonimowego) faraona, którzy byli wrogami Boga i ludu Jego wybrania.

20 B. B e c k i n g, Does Ezra Present the Return from Exile as a Second Exodus? Biblische Notizen 177/2018, s. 65-73. 
Dużo miejsca zajmuje narracja o odbudowie świątyni i murów Jerozolimy (Ezd 3-6). Odbudowa świątyni jest postrzegana jako główny warunek zachowania i rozwijania tożsamości wspólnoty powygnaniowej skupionej wokół tego miasta. Najpierw, zgodnie z rzeczywistą sytuacją historyczną, mówi się o odbudowie ołtarza ofiarniczego $(3,1-7)$. Zatem sprawowanie kultu zostało przywrócone jeszcze przed odbudową świątyni, co stawia wobec pytania, czy kult ofiarniczy w okresie wygnania zupełnie ustał i po powrocie z wygnania został wznowiony, czy raczej mamy do czynienia z jego kontynuacją w nowych okolicznościach. Podkreślając jedność i solidarność całej wspólnoty, eksponuje się rolę Jozuego (przywódca religijny) i Zorobabela (przywódca świecki), działających za panowania Dariusza (522-486) w przywróceniu kultu i wypełnieniu polecenia zawartego w Wj 20,25. Widać nacisk na wierne zachowanie rozporządzeń Tory, o której mówi się, że istnieje na piśmie (Tora Mojżesza). Podobnie jak w czasach Salomona (1Krl 8,2) odbywa się to w Święto Namiotów (Kpł 23), co odwzorowuje kalendarz kultyczny. Ofiary osobiste, czyli dobrowolne (Kpł 22,17-25; Lb 15,1-10; Pwt 12,17), stanowią kolejne potwierdzenie ciągłości kultu.

W drugim miesiącu, jak w czasach Salomona (2Krn 3,2), drugiego roku po powrocie z wygnania, czyli w kwietniu-maju 537/536 r., odbyło się uroczyste położenie fundamentów świątyni (3,8-13), która stanowiła odwzorowanie pierwszej, sprzed wygnania. Nie ma szczegółów odnośnie do odbudowy, lecz mowa o uroczystości zapowiadającej jej poświęcenie (por. $2 \mathrm{Krn}$ 7,6). Ofiary są składane tak, jak polecił Mojżesz, a kult sprawowany tak, jak polecił Dawid (1Krn 15-16; 23-26). Celebracja liturgiczna jest połączona ze spontaniczną reakcją ludu wyrażającą wdzięczność, radość i podziw. Czas kary Bożej się skończył i nastaje nowa era, czyli okres Drugiej Świątyni.

W tym miejscu pojawia się krótka narracja (4,1-5), która wiarygodnie relacjonuje konflikt, jaki zaistniał wokół projektu odbudowy 
Świątyni. ${ }^{21}$ Narrację otwiera dwojaka prezentacja delegacji przybyłej do Jerozolimy. Werset 1 przedstawia ją oczami autora Księgi Ezdrasza, natomiast w. 2 zachował jej autoprezentację. Obydwa spojrzenia bardzo się od siebie różnią.

\begin{abstract}
,Gdy usłyszeli przeciwnicy Judy i Beniamina, że wygnańcy budują świątynię dla YHWH (Pana), Boga Izraela, ${ }^{2}$ przybyli do Zorobabela oraz do przywódców rodów i powiedzieli im: «Będziemy budować z wami, bo jak wy szukaliśmy waszego Boga i Jemu my składamy ofiary od czasów Esarhaddona, króla Asyrii, który nas tu sprowadził»".
\end{abstract}

Wieści o decyzji podjęcia odbudowy świątyni przez repatriantów przybyłych z Babilonii szybko rozeszły się nie tylko w bliskim sąsiedztwie Jerozolimy, lecz i na terytorium dawnego królestwa Izraela. Dotarły z wiadomościami o odbudowie ołtarza i wznowieniu kultu ofiarniczego, odbijając się szerokim echem wśród mieszkańców żywo zainteresowanych tym, co się dzieje w Jerozolimie. Obraz rzeczywistej sytuacji na terytorium dawnego królestwa Izraela odbiega daleko od milczenia Biblii na ten temat. Asyryjska prowincja Samerina, utworzona w 721 r. przed Chr., miała pewną niezależność polityczną i ekonomiczną, stanowiąc ważny bufor w konfrontacji Asyrii z Egiptem. ${ }^{22}$ Przed wygnaniem babilońskim jej mieszkańcy utrzymywali kontakty z Jerozolimą i przybywali do świątyni celem składania ofiar. Król Ezechiasz (727-697), obchodząc święto Paschy wtedy, gdy królestwo Izraela już nie istniało, „wysłał posłów do całego Izraela i Judy, a do Efraima i Manassesa napisał także listy, żeby przybyli do świątyni Pana w Jerozolimie, aby sprawować Paschę ku czci Pana, Boga Izraela" (2Krn 30,1). Odpowiedź była

${ }^{21}$ W. C h r o s t o w s k i, Konflikt wokół odbudowy świątyni (Ezd 4,1-5). Przyczynek do transformacji religii biblijnego Izraela i narodzin judaizmu, Collectanaea Theologica 89(2019) nr 3, s. 43-83.

22 R. G a n e, The Role of Assyria in the Ancient Near East during the Reign of Manasseh, Andrews University Seminary Studies 35/1997, s. 21-32. 
zróżnicowana. „Wysłannicy szli od miasta do miasta w ziemi Efraima i Manassesa, aż do Zabulona, lecz wyśmiewano się i drwiono z nich. Jedynie niektórzy mężowie z plemienia Asera, Manassesa i Zabulona upokorzyli się i przybyli do Jerozolimy" (30,10-11). Kilkadziesiąt lat później król Jozjasz (640-609), przeprowadzając gruntowną reformę religijną, wdrażał ją także na terytorium zamieszkiwanym przez północne plemiona Manassesa, Efraima i Symeona, aż do Neftalego (34,4-7). Polecając odnowienie świątyni, zebrał fundusze także wśród plemienia Manassesa i Efraima (34,9-11). Gdy po zakończeniu wygnania odbudowano ołtarz i podjęto na nim składanie ofiar, przedstawiciele ludności mieszkającej na północ od Jerozolimy przybyli z ofertą współpracy przy odbudowie sanktuarium. Odbudowa ołtarza była przedsięwzięciem zakrojonym na niewielką skalę i ukończonym w krótkim czasie, w wyniku czego nie mieli możliwości, aby w niej współuczestniczyć. Pobudki religijne szły zapewne w parze z intencjami politycznymi. Mieszkańcy dawnego królestwa Izraela mogli się obawiać, że po zakończonej pomyślnie odbudowie świątyni i wzmocnieniu Jerozolimy repatrianci będą chcieli rozszerzyć swą hegemonię także na terytorium północne. ${ }^{23}$

W wierszu 1 przybysze zostali nazwani șārê yohûdāâh ûbinyāmīn, czyli ,przeciwnicy Judy i Beniamina”, co odzwierciedla spojrzenie nieprzyjazne wobec mieszkańców terytorium na północ od Judy. Przenosi na nich stereotypowe resentymenty, traktując „Judę i Beniamina", analogicznie jak to czyni $2 \mathrm{Krn} 11,1 ; 3,10.12 .23$ i $2 \mathrm{Krn} 15$, jako tożsamych ze wspólnotą sprzed wygnania ograniczoną do terytorium Judy ze stolicą w Jerozolimie. Już w Mezopotamii zaznaczyły się silne napięcia między dwoma zasadniczymi grupami wygnańców z dwóch części Palestyny - północnej i południowej. ${ }^{24}$ Stanowiły

${ }^{23}$ H. L a n g k a m m e r, Księgi Ezdrasza-Nehemiasza. Wstęp - przektad z oryginatu - komentarz - ekskursy, Pismo Święte Starego Testamentu II/3, Poznań-Warszawa 1971, s. 139.

${ }^{24} \mathrm{~W}$. C h r o s to w s k i, Ezechiel jako świadek asyryjskiej diaspory Izraelitów, w: t e n ż e, Asyryjska diaspora Izraelitów i inne studia, Rozprawy i Studia Biblijne 10, Warszawa 2003, s. 55-68; t e n ż e, Wizja ożywienia wyschniętych kości (Ez 37,1-14) jako świadectwo asyryjskiej diaspory Izraelitów, w: t e n ż e, Babilońskie 
kontynuację wcześniejszego zantagonizowania i narastającej wrogości, której liczne świadectwa znajdujemy w deuteronomicznym dziele historycznym (Joz-2Krl). Mimo wzajemnych antagonizmów i napięć obie zasadnicze fale wygnańców uniknęły asymilacji, co wyjaśnia ich znaczne sukcesy ekonomiczne oraz częste wybieranie imion jahwistycznych. ${ }^{25}$ Nie potrafimy powiedzieć, w jakim stopniu rzeczywiście istniała etniczna kontynuacja między repatriantami a ich przodkami deportowanymi z Judy do Mezopotamii, ${ }^{26}$ ale faktem jest, że to właśnie oni uważali siebie za ich spadkobierców. Przybywszy do Jerozolimy, nie poczuwając się do wspólnoty z pobratymcami uprowadzonymi w czasach asyryjskich, odcinali się od wspólnoty z potomkami mieszanej ludności na terytorium dawnego królestwa Izraela i mieszkańcami Judy, którzy uniknęli deportacji do Babilonii. Postrzegali siebie jako całkowicie odrębną społeczność, zintegrowaną na wygnaniu, która z nastaniem dominacji perskiej i we współpracy z nowymi władzami wzięła na siebie odpowiedzialność za ponowne zorganizowanie życia religijnego i politycznego w Jerozolimie i Judei.

„Przeciwnicy Judy i Beniamina” przybyli na spotkanie z Zorobabelem i przywódcami rodów. Spotykając się z nim, wiedzieli, że ma on wysokie ambicje polityczne ${ }^{27}$. Wywodząc się z linii królewskiej

deportacje mieszkańców Jerozolimy i Judy oraz inne studia, Rozprawy i Studia Biblijne 34, Warszawa 2009, s. 80-108; t e n ż e, Asyryjska diaspora Izraelitów $w$ świetle Księgi Ezechiela. Wojciechowi Pikorowi wodpowiedzi, w: t e n ż e, Trzecia Światynia w Jerozolimie i inne studia, Rozprawy i Studia Biblijne 44, Warszawa 2012, s. 84-107.

25 E. Yamauchi, The Eastern Jewish Diaspora under the Babylonians, w: M. W. Chavalas, K. Lawson Younger jr. (red.), Mesopotamia and the Bible. Comparative Explorations, Grand Rapids (MI) 2002, s. 356-377; R. Zadok, Judeans in Babylonia - Updating the Dossier, w: U. Garbay, Sh. Secunda (red.), Encounters by the Rivers of Babylon. Scholarly Conversations Between Jews, Iranians and Babylonians in Antiquity, Texts and Studies in Ancient Judaism 160, Tübingen 2014, s. 109-129.

26 B. B e c k in g, Ezra's Re-enactment of the Exile, w: L. L. G r a b b e, Leading Captivity Captive. "The Exile” as History and Ideology, JSOTSuppl. 278, European Seminar in Historical Methodology 2, Sheffield 1998, s. 40-61.

27 J. C i e c i e l ą g, Zerubbael and His Role in the Creation of Yehud Province, Polish Journal of Biblical Research 10/2011, s. 57-62. 
i sprawując funkcję przywódcy świeckiego, został uznany za właściwego adresata oferty współpracy w dziele odbudowy świątyni, które wymagało wielkich nakładów finansowych i dużych zasobów ludzkich w postaci murarzy i rzemieślników. Deklaracja włączenia się w dzieło odbudowy świątyni zapowiadała skuteczne włączenie się we wspólną realizację wzniosłego przedsięwzięcia.

Werset 2 przekazuje sedno oferty przedstawionej Zorobabelowi i starszyźnie jerozolimskiej przez przybyszów z północnej części kraju. Kim byli owi przybysze? Po pierwsze, w miejsce deportowanych Izraelitów Asyryjczycy sprowadzili ludność obcego pochodzenia, lecz mimo upadku państwa przetrwały lokalne miejsca kultu, zatem przybysze przyjmowali lokalne wierzenia i obrzędy. Po drugie, także w okresie babilońskim większość tamtejszej ludności stanowili Izraelici, czciciele Jahwe. ${ }^{28}$ Ponieważ od VIII do VI w. Samaria była centrum administracyjnym, od którego zależała Jerozolima, przybysze czują się zobowiązani do współuczestniczenia w realizacji ważnej decyzji o profilu religijnym i politycznym. Po trzecie, wielu rodowitych Izraelitów zmieszało się z Judejczykami, co skutkowało rodzinnymi migracjami z Jerozolimy i Judy do prowincji Samerina. Konsekwentnie, etniczne podłoże późniejszej schizmy samarytańskiej było bardzo zróżnicowane. ${ }^{29}$

Deklaracja „będziemy budować z wami” (nibnne ${ }^{h}$ immākem) jednoznacznie wskazuje, do kogo należy pierwszeństwo i kto będzie przewodził w odbudowie świątyni. Przybysze chcą się włączyć w realizację planów, które zostały podjęte, i w niej współuczestniczyć. Uzasadniając wolę współpracy, wyjaśniają: „Bo jak wy szukamy waszego Boga i Jemu składamy ofiary" (kî knākem niḍrôš lệ̉ōhêkem (Wəlō’) [Wolô] วănáḥnû zōḅhîm). Kontynuowanie kultu ofiarniczego odbywało się zapewne w tych samych ośrodkach, które w okresie istnienia królestwa Izraela służyły jako miejsca kultu. Przybysze

28 A. Z e r t a 1, The Province of Samaria (Assyrian "Samerina") in the Late Iron Age (Iron Age III), w: O. L i p s c h it s, M. O e m in g (red.), Judah and the Judeans in the Persian Period, Winona Lake (IN) 2006, s. 377-412.

29 R. I r u d a y a, Who are the Samaritans? Vidyajyoti 68/2004, s. 576-594. 
nie kierują się względami etnicznymi ani politycznymi, lecz solidarnością religijną. ${ }^{30}$ Dawne, sięgające panowania Ezechiasza i Jozjasza, wysiłki pozyskania ich dla wiary w Boga i oddawania Mu czci w Jerozolimie również w nowych warunkach przynoszą pozytywne rezultaty. Wyrażenie ,jak wy szukamy Boga” podejmuje formułę znaną z Księgi Powtórzonego Prawa $(4,29 ; 12,5)$ i nauczania proroków nawołujących do „szukania Jahwe”, czyli zaprzestania polegania na bezpieczeństwie o charakterze politycznym i położenia kresu oddawaniu czci bóstwom pogańskim (Iz 8,19; 31,3; Jr 8,2). W Pierwszej i Drugiej Księdze Kronik „szukanie [ $d r s ̌$ ] Jahwe” wskazuje na tożsamość Jego wyznawców ${ }^{31}$ i szczere pragnienie przylgnięcia wyłącznie do Pana. ${ }^{32}$ Mimo że $2 \mathrm{Krl} 17$, przedstawiając sytuację po zagładzie Samarii i królestwa Izraela, zarzuca mieszkańcom północnej części kraju godny potępienia i napiętnowania synkretyzm religijny, po zakończeniu wygnania babilońskiego przybysze do Jerozolimy deklarują wiarę w Boga. Było tak, mimo że mają świadomość swej odmienności etnicznej, co znalazło wyraz w wyrażeniach ‘immāknem $i$ kāâkem oraz 'ănáhnû i 'ōtánû, czyli ,z wami” i ,,jak wy” oraz ,my” i „,nas”. W przekonaniu przybyszów różnice etniczne nie przekreślają tego, co wspólne i co powinno jednoczyć, a mianowicie wiary w Jahwe, który odbiera cześć w Jerozolimie. Druga część deklaracji przybyszów skupia się na poprawności sprawowanego przez nich kultu. W tym miejscu mamy do czynienia z radykalną interwencją masoretów w tekst, który poddali własnej wokalizacji. ${ }^{33}$ Zaprzeczając

30 D. J. She pherd, Commentary on Ezra, w: D. J. S h e phe rd, Ch. J. H. Wrig h t, Ezra and Nehemiah, The Two Horizons Old Testament Commentary, Grand Rapids (MI) 2018, s. 21.

31 D. De n n i nge r, drš, w: W. A. Van Ge meren (red. nacz.), The New International Dictionary of Old Testament Theology and Exegesis, t. 1, Carlisle 1996, s. 996-997.

32 C. B e g g, "Seeking Yahweh" and the Purpose of Chronicles, Louvain Studies 9/1982, s. 128-142; D. M c C a r t h y, Covenant and Law in Chronicles-Nehemiah, Catholic Biblical Quarterly 44/1982, s. 31.

33 W. C h r o s t o w s k i, Konflikt wokól odbudowy świątyni, s. 48-49. 
autodeklaracji przybyszów, całkowicie odwrócili jej sens, jednak ich interwencja jest zbyt nachalna, żeby jej nie zauważyć.

Co się tyczy wyrażenia „od czasów Esarhaddona, króla Asyrii, który nas tu sprowadził” (mîmê 'ēsar haddōn mélek 'aššûr hamma ‘̆le ${ }^{h}$ 'ōtánû $p \bar{o}^{h}$ ), Biblia wspomina o przymusowych deportacjach, których na krótko przed - za panowania Tiglat-Pilesera III (745-727), Salmanassara V (727-722) - i po zagładzie Samarii za panowania Sargona II (722-705) - dokonali Asyryjczycy. ${ }^{34} \mathrm{Nie}$ mówi o późniejszych deportacjach, do których aluzję znajdujemy w słowach delegacji przybyłej do Jerozolimy oraz w świadectwach pozabiblijnych. Deportacje miały charakter dwukierunkowy. Według 2Krl 17,24, wobec depopulacji kraju Sargon II dokonał częściowego zaludnienia Samarii i jej okolic. Tę politykę kontynuowali jego następcy, czyli Esarhaddon (681-668) i Assurbanipal (669-629). ${ }^{35}$ Do asyryjskiej prowincji Samerina napłynęła trudna do ustalenia, lecz niemała, liczba ludności z różnych rejonów Mezopotamii. ${ }^{36}$ Adaptując się do nowego środowiska, przejmowali wiarę w Jahwe i miejscowe zwyczaje. Druga Księga Królewska (17,24-28) podaje, że odbywało się to za przyzwoleniem władcy Asyrii. Lokalna ludność dawnego królestwa Izraela, która ostała się wobec deportacji, oraz przymusowo

${ }^{34} \mathrm{~K}$. L a w s o n Y o u n g e r, The Deportations of the Israelites, Journal of Biblical Literature 117/1998, s. 201-227; B. O d e d, The Settlements of the Israelite and Judean Exiles in Mesopotamia in the 8th-6th Centuries BCE, w: G. G a 1 i 1, M. W e i n f e $1 \mathrm{~d}$ (red.), Studies in Historical Geography and Biblical Historiography Presented to Zecharia Kallai, Vetus Testamentum Suppl. 81, Leiden et al. 2000, s. 91-103; W. C h r o s t o w s k i, ,Nic nie zostało, jak tylko samo pokolenie Judy” (2Krl 17,18n.) - czy naprawdę? w: t e n ż e, Asyryjska diaspora Izraelitów i inne studia, s. 35-54. S. H. Hor n, P. Ky le M c C a r t e r j r., Podzielona monarchia. Królestwa Judy i Izraela, w: H. S h a n k s (red.), W. C h r o s to w s k i (tłum. i red. wyd. pol.), Starożytny Izrael. Od Abrahama do zburzenia światyni jerozolimskiej przez Rzymian, Podręczniki Biblijne 1, Warszawa 2018, s. 245-259.

${ }_{35}$ N. N a' $m$ a n, Population Changes in Palestine Following Assyrian Deportations, Tel Aviv 20(1993) nr 2, s. 104-124.

${ }^{36} \mathrm{Na}$ temat asyryjskich kolonistów w Samarii zob. np. E. N o d e t, A Search for the Origins of Judaism. From Joshua to the Mishnah, Journal for the Study of the Old Testament 248, Sheffield 1997, s. 154-160. 
deportowana z Mezopotamii ludność obcego pochodzenia mieszały się ze sobą i otrzymały kapłana uprowadzonego niegdyś z Samarii do Mezopotamii, który „zamieszkał w Betel i pouczał ich, jak mają oddawać cześć Panu” (w. 28). Członkowie delegacji przybyłej do Jerozolimy byli więc potomkami ludności sprowadzonej około półtora stulecia wcześniej z Mezopotamii na terytorium dawnego królestwa Izraela, przemieszanej z Izraelitami, którzy ocaleli z zagłady asyryjskiej i nie poszli na wygnanie. Deklarując wiarę w Jahwe i pragnienie oddawania Mu czci w świątyni jerozolimskiej, wcale nie postrzegali siebie jako pogan, mieli więc ukształtowaną tożsamość religijną. Ich pragnieniem było przyłączenie się do realizacji projektu odbudowy sanktuarium i potwierdzenie jedności wyznawców jedynego Boga. ${ }^{37}$ Ich nastawienie nie było wrogie, a intencje nie były niecne. Okoliczności ich przybycia wpisują się we wspomnianą, sięgającą panowania Ezechiasza i Jozjasza, tradycję kontaktów religijnych z Jerozolimą, która trwała również podczas wygnania babilońskiego. ${ }^{38}$ Jej członkowie mogli być związani z sanktuarium w Betel, które przetrwało podbój asyryjski i reformę Jozjasza, dali wyraz pragnieniu włączenia się w dzieło, które uznawali za potrzebne i ważne. Nie ma żadnych powodów, aby sądzić, że „,ich propozycja pomocy przy odbudowie świątyni nie była szczera". ${ }^{39}$ Mimo to terminologia opisująca ich

37 Por. pogląd wyrażony przez H. Langkammera: „Nie należy przypuszczać, by koloniści od razu myśleli o objęciu całkowitego kierownictwa nad budową. Chyba jednak nie porzucali nadziei, że kiedyś to nastąpi. A może kierownictwo chciano przekazać władzom perskim prowincji Samarii, skoro Judejczycy stanowczo odrzucając propozycję wrogów powołują się na naczelną władzę w państwie perskim, tj. na samego króla. Otóż Cyrus polecił Judejczykom odbudowę świątyni, jednakże wyłącznie im. Stąd to wykluczają oni kategorycznie wszelkie obce plemiona od współudziału, choć zasadniczy powód jest inny: chodzi o autentycznego Izraela, tj. o gminę kultyczną, która wraca z niewoli i wyłącznie ona decyduje o sobie i o swoich przedsięwzięciach"; H. L a n g k a m m e r, Księgi Ezdrasza-Nehemiasza, s. 139.

38 W. C h r o s t o w s k i, Konflikt wokól odbudowy świątyni, s. 50-57.

39 J. H. Walto n, V. H. Mat thew s, M. W. Chav a la s, Komentarz historyczno-kulturowy do Biblii Hebrajskiej, Prymasowska Seria Biblijna 24, Warszawa 2005, s. 519. 
w w. 1 nie zostawia złudzeń, że nie byli w Jerozolimie mile widziani, co więcej, pejoratywne określenie ,przeciwnicy”, „wrogowie” zakłada wrogość i złe zamiary z ich strony.

\section{Odpowiedź starszyzny jerozolimskiej (Ezd 4,3-5)}

Wprawdzie praktyki kultu Jahwe na północ od Judei różniły się od tych, jakie sprawowano w świątyni, lecz starszyzna jerozolimska nie podjęła żadnej próby, by je sprostować czy ulepszyć. Gdyby odpowiedź z jej strony była pozytywna, to późniejsza historia starożytnego Izraela i jego religii potoczyłaby się zupełnie inaczej. Ale podczas gdy przybyszami kierowały przesłanki religijne, przywódcy jerozolimscy dali przede wszystkim wyraz podejściu etnicznemu i politycznemu.

,30dpowiedział im Zorobabel oraz Jozue i pozostali przywódcy rodów Izraela: «Nie wolno wam z nami budować Domu dla naszego Boga, ponieważ my sami zbudujemy dla YHWH (Pana), Boga Izraela, jak polecił nam król Cyrus, król perski». ${ }^{4}$ A lud ziemi krępował ręce ludu Judy i przeszkadzał im budować.

${ }^{5}$ I przeszkadzając im, spiskowano przeciw nim przez cały czas panowania Cyrusa, króla perskiego, aż do panowania Dariusza, króla perskiego".

Werset 3 zawiera informację o tym, kto udzielił odpowiedzi przybyszom: Zorobabel oraz Jozue i pozostali przywódcy rodów Izraela. Pierwszymi rozmówcami przybyszów, o czym świadczy w. 1, byli Zorobabel i przywódcy rodów Izraela, czyli czołowi przedstawiciele władzy świeckiej. Określenie rā̄̌šê hāāābôt (,głowy/przywódcy ojców/rodów"), które pojawia się w w. 3, a także w Ezd 2,68; 8,1 i Ne 8,13; 11,13 i in., dotyczy „starszych Judy” wzmiankowanych w aramejskim fragmencie Księgi Ezdrasza (5,5.9; 6,7.8.14), którzy przejęli przywództwo podczas powrotu z wygnania i podjęli 
postanowienie o odbudowie świątyni. ${ }^{40}$ Wzmianki o Jozuem, który był przywódcą religijnym, nie ma w w. 1 z informacją o pierwszym adresacie deklaracji przybyszów. Nie ma żadnej potrzeby, by uzgadniać w. 1 z w. 3, ponieważ lakonicznie opowiedziane wydarzenie przebiegało w trzech etapach: 1. delegacja przedstawiła Zorobabelowi propozycję współudziału w odbudowie świątyni; 2 . ta propozycja została przedstawiona arcykapłanowi Jozuemu i z nim skonsultowana; 3. Zorobabel, Jozue i lokalna starszyzna razem udzielili wspólnie ustalonej odpowiedzi. To wskazuje na ścisłą współpracę Zorobabela z Jozuem oraz znaczenie, jakie we wspólnocie repatriantów miał arcykapłan. Podkreślenie roli Zorobabela potwierdza ciągłość dynastyczną, a Jozuego - ciągłość kultową. ${ }^{41}$ Wyłaniają się zręby struktury politycznej i administracyjnej społeczności żydowskiej oparte na status quo sprzed wygnania babilońskiego, poddane znacznej modyfikacji i adaptacji ukierunkowanej ku kształtowaniu nowej przyszłości.

Nie wiadomo, jaka byłaby odpowiedź Zorobabela i lokalnej starszyzny świeckiej, gdyby wyłącznie od nich zależało podjęcie decyzji. Znamy natomiast odpowiedź udzieloną po konsultacji z arcykapłanem Jozuem. Przybysze, świadomi odmienności etnicznej, powoływali się na wspólnotę w wierze w Boga i kulcie, ale religijne autorytety jerozolimskie kwestionują i całkowicie wykluczają ich roszczenia. Wyrażenie ,nie wolno wam z nami” (lō’-lākem wālānû liḅnôt báyit lē’ōhếnû) podkreśla separację, której nie da się przezwyciężyć, aczkolwiek nie wyjaśnia się, skąd się wzięła ani na czym polega. W tle pobrzmiewają zarzuty tej samej natury, które znalazły wyraz w deuteronomicznej narracji o przyczynach i następstwach upadku Samarii i królestwa Izraela, których częścią było sprowadzenie ludności obcej etnicznie i religijnie. Aczkolwiek okazywała podatność na przyjmowanie wiary w Jahwe, autor Drugiej Księgi Królewskiej

40 R. A 1 b e r t z, A History of Israelite Religion in the Old Testament Period, t. 1: From the Exile to the Maccabees, London 1994, s. 446-447.

${ }^{41} \mathrm{~A}$. S é $\mathrm{r}$ a $\mathrm{n}$ d o u r, Les récits bibliques de la construction du second temple: leurs enjeux, Transeufratene 11/1996, s. 9-32. 
zaznaczył: „Ludy te czciły więc Pana, a zarazem służyły swoim bożkom. Również ich dzieci oraz dzieci ich dzieci postępują tak, jak czynili ich ojcowie - aż do dnia dzisiejszego" (17,41). Robert North słusznie zauważył: „Zorobabel nie zaprzecza ani nie kwestionuje, że owi Samarytanie (lub ich pochodzący z Judy współpracownicy) naprawdę czcili Jahwe - ulega raczej postawie zatwardziałości i rasowym przesądom, przypisując ich mieszanej krwi braki, jakie wkradły się do przestrzegania najmniejszych zapisów prawa (Ag 2,12; Za 7,2; $\mathrm{J} 8,48)$ ". ${ }^{42}$ Odbudowa świątyni miała nie tylko, a nawet nie tyle, wymiar materialny, ile religijny i ideologiczny. Starszyzna jerozolimska deklaruje, że będzie to „Dom dla naszego Boga”, w czym wyraźnie widać roszczenia do wyłączności i podkreślenie, że sanktuarium będzie stanowiło trzon tożsamości repatriantów kształtującej się po powrocie z wygnania. Jeżeli delegacja miała związki z sanktuarium w Betel, co bardzo prawdopodobne, odrzucenie jej oferty świadczy, że sprawowany tam kult uznano w Jerozolimie za nielegalny. Rodzi się tożsamość żydowska, wykluczająca ,innych” od współudziału w kulcie, nawet gdy deklarowali tę samą wiarę w Jahwe i sprawowanie tych samych praktyk religijnych. Określenie „,nasz Bóg” ma wszystkie znamiona ekskluzywizmu religijnego, zamkniętego wobec każdego, kto nie należy do wąskiej wspólnoty złożonej z repatriantów. U podstaw tej odmowy były też względy polityczne: kształtuje się autonomiczna wspólnota zogniskowana wokół projektu odbudowy świątyni.

Nie mając króla ani świątyni, repatrianci kładli nacisk na konsolidację i eksponowanie roli gôlâ, odcinając się od innych pobratymców. ${ }^{43}$ Wyjątek stanowiły wspólnoty w Babilonii, z którymi podtrzymywano kontakty, broniąc swej niezależności w sprawach

${ }^{42}$ R. N o r th, Księga Ezdrasza i Księga Nehemiasza, w: R. E. B r o w n, J. A. F i t z m y e r, R. E. M u r p h y (red. nauk. wyd. oryg.), W. C h r o s t o w s k i (red. nauk. wyd. pol.), Katolicki komentarz biblijny, Prymasowska Seria Biblijna 17, Warszawa 2001, s. 347.

${ }^{43}$ Ch. E. C a r t e r, Ideology and Archaeology in the Neo-Babylonian Period. Excavating Text and Tell, w: O. L i p s c h it s, M. O e m in g (red.), Judah and the Judeans in the Persian Period, s. 301-322, z konkluzją: "This ideology has ruled the day for 2500 years and continues to dominate the interpretative landscape". 
przywództwa i kwestiach religijno-moralnych. ${ }^{44}$ Uzasadniając odmowę, nie podaje się żadnych argumentów religijnych, a jedynie polityczny: „Jak polecił nam król Cyrus, król perski”. Niezależnie od kwestii historyczności dekretu Cyrusa, Księga Ezdrasza przykłada do niego ogromną wagę. Odpowiedź udzielona przybyszom sugeruje, że ich ewentualne włączenie się w odbudowę sanktuarium byłoby odebrane jako niesubordynacja wobec Cyrusa, bo polecenie, które wydał, powinno być wykonane dokładnie zgodnie z jego wolą. W ten sposób ciężar uzasadnienia decyzji odmownej i dalszego roztrząsania tej sprawy przenosi się ze starszyzny jerozolimskiej na pogańskiego króla. Powołanie się na dekret Cyrusa to klarowny argument polityczny, który ma uzasadniać roszczenia do wyłączności w odbudowie świątyni. Jerozolimska starszyzna zdecydowała o separacji od pobratymców mieszkających na północy, a wykluczając ich z dzieła odbudowy świątyni, odsunęła od przyszłego udziału w sprawowanym w niej kulcie. Podczas gdy przybysze eksponowali ciągłość z religią Izraela, co później podjęli Samarytanie, Zorobabel, Jozue i pozostali przełożeni wspólnoty jerozolimskiej kładą podwaliny pod ograniczenie określenia „Izrael” wyłącznie do Judy i Beniamina oraz jego zawłaszczenie, kosztem plemion północnych. ${ }^{45}$ Po tym wydarzeniu mieszkańcy północy usztywnili stanowisko względem Jerozolimy. Mieli świadomość ciągłości z religią sprzed wygnania, która była fundamentalna dla ich samookreślania się jako wyznawców jedynego Boga. Być może właśnie to zbyt bliskie pokrewieństwo i podobieństwo było postrzegane z perspektywy jerozolimskiej jako zagrożenie. ${ }^{46}$ Antysamarytańskie nastawienie widoczne

44 P. R. B e d for d, Diaspora: Homeland Relations in Ezra-Nehemiah, Vetus Testamentum 52/2002, s. 147-165.

45 L. L. G r a b b e, Israel's Historical Reality after the Exile, w: B. B e c k in g, M.C.A. K o r p e 1 (red.), The Crisis of Israelite Religion. Transformation of Religious Tradition in Exilic and Post-Exilic Times, Old Testament Studies 42, Leiden 1999, s. 9-44.

46 G. N. K n o p p e r s, Revisiting the Samarian Question in the Persian Period, w: O. L i p s c h it s, M. O e m in g (red.), Judah and Judeans in the Persian Period, s. 265-289. 
w deuteronomicznym, ${ }^{47}$ a później również w kronikarskim dziele historycznym, stoi na usługach określonej ideologii. Po odmowie, z jaką spotkali się przybysze, ich roszczenia do współdecydowania o sprawach całej wspólnoty wyznawców jedynego Boga coraz bardziej słabły. W okresie hellenistycznym wola współpracy ustąpiła miejsca rywalizacji i konfrontacji, co skutkowało okrzepnięciem nowej wspólnoty religijnej skupionej wokół góry Garizim i rywalizującej z Jerozolimą.

Werset 4 wprowadza trzecią, obok starszyzny jerozolimskiej i przybyszów z północy, grupę uczestników narastającego konfliktu. Określenie 'am-hāấreṣ („lud ziemi”) przed wygnaniem babilońskim odnosiło się do ludności zamieszkującej daną prowincję, odróżnianą lub kontrastującą z królem oraz jego dworzanami i urzędnikami, a także z możnymi, kapłanami i prorokami. Nie odnoszono go do mieszkańców Jerozolimy jako miasta królewskiego, zamieszkiwanego przez ludność mocno związaną z władcą i świątynią ${ }^{48}$ Natomiast repatrianci odnieśli je do ludności autochtonicznej zamieszkującej Jerozolimę i okolice, która uniknęła deportacji oraz skutków najazdów babilońskich w postaci głodu czy epidemii. ${ }^{49}$ Gdy kraj uległ depopulacji, napłynęła trudna do ustalenia liczba okolicznych sąsiadów, którzy w ciągu kilkudziesięciu lat przemieszali się z lokalną ludnością. Byli wśród niej także Izraelici, którzy, poczynając od upadku królestwa Izraela, przemieszczali się na południe i mieszali z Judejczykami. ${ }^{50}$ Istnieje pogląd, że tłumaczyłoby to włączenie tradycji

47 R. H o b s o n, The Memory of Samaria in the Books of Kings, w: D. V. E d e 1 $\mathrm{m}$ a n, E. B e n Zvi (red.), Memory and the City in Ancient Israel, Winona Lake (IN) 2014, s. 219-229.

48 E. L i pińs k i, 'am. III. Collective Sense, w: G. J. B o t t e r w e c k, H. R ing g r e n, H.-J. F a b r y (red.), Theological Dictionary of the Old Testament, t. XI, Grand Rapids (MI)-Cambridge 2002, s. 174.

49 A. F a u s t, Deportations and Demography in Sixth-Century B.C.E. Judah, w: J. L. W r i g h $\mathrm{t}$ (red.), Interpreting Exile. Interdisciplinary Studies of Displacement and Deportation in Biblical and Modern Contexts, Atlanta 2011, s. 91-103.

50 W. S c hü t t e, Wie wurde Juda israelitiesiert? Zeitschschrift für Alttestamentliche Wissenschaft 124/2012, s. 52-72. 
znanych w królestwie Izraela do Biblii, ${ }^{51}$ ale bardziej prawdopodobne, że ta integracja dokonała się na wygnaniu, w warunkach spotkania diaspory asyryjskiej z (dobrowolnymi i przymusowymi) migrantami z Judy. Nawet jeżeli przesadne są szacunki, że ok. 50\% populacji Judy miało pochodzenie izraelskie/izraelickie, ${ }^{52}$ jednak ów odsetek mógł być relatywnie duży. Sytuacja była więc w pewnym sensie analogiczna jak na wygnaniu oraz w północnej części kraju. Postrzeganie „ludu ziemi”, wyznającego tę samą wiarę, jako obcych w silnym kontraście z „synami wygnania”, czyli repatriantami, świadczy, że napięcia były dramatyczne. ${ }^{53}$ Miejscowa ludność, z uwagi na swoje pochodzenie, była przez repatriantów postrzegana jako „skażona” bądź podatna na sprzyjanie wpływom asyryjsko-aramejskim, jakie dawały znać o sobie w części północnej. ${ }^{54}$ Większość mieszkańców Jerozolimy i jej okolic stanowili ludzie trudniący się rolnictwem i pasterstwem, którzy podczas wygnania weszli w mieszane związki małżeńskie (Ne 13,23). W Księdze Ezdrasza (9,1-2.11; 10,2.11) i Księdze Nehemiasza (10,29,31-32) mówi się o nich z nieukrywaną pogardą, zarzucając im brak znajomości Tory, nieprzestrzeganie szabatu i inne błędy. ${ }^{55} \mathrm{~W}$ tych warunkach określenie cam-hāóáres stało się pejoratywne. Nastawienie starszyzny wobec przybyszów z północy przeniosło się również na lokalną ludność. Tak samo jak mieszkańcy północnej części kraju, została odsunięta od projektu odbudowy ${ }^{56}$ i została przez repatriantów, którzy zdominowali życie polityczne

51 I. F in kels te i n, Migration of Israelites into Judah after 720 BCE. An Answer and un Update, Zeitschrift für Altestamentliche Wissenschaft 127/2015, s. 188-206.

52 E. A. K n a u f, Bethel. The Israelite Impact on Judaean Language and Literature, w: O. L i p s c h it s, M. O e m ing (red.), Judah and the Judeans in the Persian Period, s. 291-349.

53 J. W i m m e r, Inside/Outside the Community, The Bible Today 37/1999, s. 217-221.

54 S. D ł u g o bors k i, Wpływ imperialnej Asyrii na religie Judy, Scripta Biblica et Orientalia 3/2011, s. 143-156.

55 E. Li i iń sk i, 'am, s. 175.

${ }^{56}$ Na temat rekonstrukcji życia w Judzie po zburzeniu świątyni jerozolimskiej zob. M. B. Mo o r e, B. E. Kelle, Biblical History and Israel's Past. The 
i religijne, odsunięta od wpływu na najważniejsze decyzje. Szukając uzasadnienia dla odmowy, można się domyślać, że wygnanie było traumatycznym doświadczeniem, które tłumaczy nacisk na separację i czystość charakterystyczny w analogicznych sytuacjach, aż po współczesność. ${ }^{57}$ Ale to nie był jedyny, a nawet najważniejszy czynnik. Widać konsekwentne zawłaszczanie koncepcji Izraela, które dochodzi do głosu w koncepcji przynależności do plemienia Judy i Beniamina ograniczonej wyłącznie do tych, którzy powrócili z wygnania. Repatrianci mieli mocne poparcie władz perskich, wykorzystując je do utrwalenia swojej pozycji i wpływów. Tworzyło się podglebie dla gruntownej reformy przeprowadzonej w połowie V w. przed Chr. przez Ezdrasza, której trzon stanowiła radykalna czystka etniczna polegająca na oddaleniu „cudzoziemskich” żon i ich dzieci (Ezd 9-10).

Werset 5 usprawiedliwia kilkunastoletnie przerwanie prac nad odbudową świątyni, które trwało od powrotu z wygnania w 539 r. do panowania króla Dariusza (520-485). Nie dysponujemy biblijnymi ani pozabiblijnymi świadectwami jakiegokolwiek zewnętrznego sprzeciwu wobec odbudowy świątyni, tak wielkiego, żeby skutkował całkowitym wstrzymaniem prac rozpoczętych przez położenie fundamentów. Natomiast z Księgi Aggeusza wyłania się zupełnie odmienny obraz. W pierwszym dniu szóstego miesiąca drugiego roku panowania Dariusza, czyli w 520 r. przed Chr., prorok skierował do Zorobabela, syna Szealtiela, namiestnika Judy, oraz do arcykapłana Jozuego, syna Josadaka, słowa dosadnego napomnienia. W nawiązaniu do głosów: „Jeszcze nie nadszedł czas, aby odbudować dom Pana” (Ag 1,2), retorycznie pytał: „Czy to jest czas stosowny dla was, byście spoczywali w domach wyłożonych płytami, podczas gdy ten

Changing Study of the Bible and History, Grand Rapids (MI)-Cambridge (U.K.) 2011, s. 367-388.

57 D. L. S m it h - C h r i s t o p h e r, Reassessing the Historical and Sociological Impact of the Babylonian Exile (597/587-539 BCE), w: J. M. S c ot t (red.), Exile: Old Testament, Jewish and Christian Perspectives, Journal for Study of Judaism Suppl. 56, Leiden 1997, s. 7-32. 
Dom leży w gruzach?" $(1,4)$. Po retorycznym pytaniu i refleksji, do jakiej ono zobowiązuje, następuje polecenie wydane w imieniu Boga: „Zastanówcie się dobrze nad swoim postępowaniem. Wyjdźcie w góry i sprowadźcie drewno, a odbudujcie ten Dom, abym sobie w nim upodobał i odbierał cześć - mówi Pan" (1,7-8). Adresatami napomnienia prorockiego są te same osoby, czyli Zorobabel i Jozue, które kilkanaście lat wcześniej odpowiedziały negatywnie na propozycję współpracy przy odbudowie świątyni zgłoszoną przez przybyszów z północnej części kraju. Odrzucając ją, nie przystąpiono do dzieła, którego wkrótce zaniechano nie w wyniku sprzeciwów, które je uniemożliwiły, ale wskutek skupienia się, co napiętnował prorok Aggeusz, na zabiegach o własną pomyślność. W Ezd 4,1-5 widać wyraźnie, że określenie „Juda i Beniamin” nie obejmuje już wszystkich potomków należących do tych plemion, bo zostało zredukowane wyłącznie do repatriantów.

\section{Projekt nowej przyszłości: judaizm}

Informacja o kilkunastoletnim zaniechaniu prac przy odbudowie świątyni nie zawiera żadnych szczegółów. Narracja na ten temat została gwałtownie przerwana przez obszerną narrację (Ezd 4,6-24) o wydarzeniach, które miały miejsce kilkadziesiąt lat później - za panowania Kserksesa (485-465) i Artakserksesa (464-424) i dotyczyły zupełnie innej sprawy, a mianowicie odbudowy murów Jerozolimy. Po niej, tak samo nagle, wraca temat wznowienia prac i dokończenia odbudowy świątyni $(5,1-6,18)$ oraz opis uroczystych obchodów Paschy (6,19-22). Wielu komentatorów Księgi Ezdrasza nie kryje zakłopotania tak rozbudowaną dygresją, lecz uzasadnienie jej obecności w tym miejscu nie wydaje się trudne. Relacjonując napięcia wokół odbudowy świątyni, które skutkowały odmową współpracy z przybyszami z północy deklarującymi tę samą wiarę w Boga, autor poczuł się zwolniony z jakiegokolwiek usprawiedliwiania udzielonej im odmowy. Delegacji, która przybyła $z$ dobrym nastawieniem, przypisuje się te same niecne intencje, które później dały o sobie znać 
we wrogich wystąpieniach podejmowane przez zupełnie inne osoby i środowiska podczas odbudowy murów miasta.

Deuteronomistyczne dzieło historyczne i kronikarskie dzieło historyczne, jako „księgi historyczne”, sąsiadują ze sobą w Biblii chrześcijańskiej, ale nie w Biblii żydowskiej, która umieszcza je w dwóch różnych zbiorach - Proroków i Pism. Całości, na którą składają się Księgi Jozuego - Druga Księga Królewska, judaizm przyznał cechy profetyczne, traktując profetyzm jako religijną ocenę przeszłości i teraźniejszości z myślą o kształtowaniu przyszłości. Dla odmiany retrospekcja przeszłości zawarta w Pierwszej Księdze Kronik - Księdze Nehemiasza, aczkolwiek wywarła ogromny wpływ na tożsamość żydowską, ma odmienny status. W jednym i drugim przypadku pamięć została poddana kryteriom i regułom uwarunkowań i potrzeb istniejących wtedy, gdy ją utrwalano na piśmie. Dlatego obydwa spojrzenia różnią się od siebie..$^{58}$ Jedna z istotnych różnic między dziełami Deuteronomisty i Kronikarza polega na tym, że to pierwsze odrzuca kult i kapłaństwo poza Jerozolimą jako nielegalne, lecz zachowuje pamięć o próbach pojednania religijnego i dopuszczenia mieszkańców dawnego królestwa Izraela, czyli plemiona północne, do udziału w kulcie sprawowanym w Jerozolimie, a więc i do jedności narodowej. W dziele Kronikarza daje się zauważyć stopniowanie:

- Pierwsza i Druga Księga Kronik, z licznymi nawiązaniami do zbioru określanego jako Prorocy wcześniejsi (Joz - 2Krl), nie rozwija wątku jedności całego narodu Izraela ani go nie promuje, aczkolwiek wzmiankuje najważniejsze próby przywrócenia jedności kultowej podejmowane za panowania Ezechiasza (2Krn 30,1) i Jozjasza (34,4-7). W narracji 2Krn 10-36 terytorium określone w Księdze Królewskiej uległo pewnemu

58 E. B e n Z v i, Chronicles and Samuel-Kings: Two Interacting Aspects of a Memory System in the Late Persian/Early Hellenistic Period, w: U. B e c k e r, H. B e z z e 1 (red.), Rereading the "relecture"? The Question of (Post)chronistic Influences in the Latest Redactions of the Book of Samuel, Tübingen 2014, s. 41-56. 
rozszerzeniu, co, jak sugeruje I. Finkelstein, ${ }^{59}$ odzwierciedla sytuację z okresu panowania hasmonejskiego, stanowiącej spełnienie politycznych postulatów nowej przyszłości zawartych w dziele Kronikarza.

- Księga Ezdrasza, kontynuując ujęcie zawarte w Pierwszej i Drugiej Księdze Kronik, coraz bardziej je zawęża, eksponując plemiona Judy i Beniamina. Nie do przecenienia jest wartość informacji na temat rozpoczęcia odbudowy świątyni. Projektu na pewien czas zaniechano, bo wkrótce po powrocie z wygnania starszyzna jerozolimska opowiedziała się za zdecydowaną separacją nie tylko od ludności z północnej części kraju, lecz i od tych mieszkańców Judei i ich potomków, którzy uniknęli wygnania. Ta decyzja uprawomocniła nową sytuację, a zarazem projekt nowej przyszłości. Jego trzon polega na tym, że jedynie wygnańcy i ich potomkowie oraz pobratymcy przebywający nadal w Mezopotamii, traktują siebie jako „Izrael”, odmawiając tej godności wszystkim pozostałym.

- Księga Nehemiasza jeszcze bardziej radykalizuje tę perspektywę, a przechodząc od płaszczyzny religijnej do etnicznej, zachowuje i podtrzymuje absolutny zakaz zawierania małżeństw mieszanych.

Konflikt, o którym mowa w Ezd 4,1-5, stanowi kwintesencję sporu o ekskluzywistyczny albo inkluzywistyczny charakter religii Izraela, którego trzon stanowiła koncepcja „ludu Bożego"60 i pytanie, czy kult Jahwe ogranicza się do jednego ludu, czy ma zasięg szerszy, a nawet uniwersalny. Wyłączenie lokalnej ludności z uczestnictwa w nim nie było całkowite, skoro uczestniczyła w uroczystych ob-

59 I. F i n k e $1 \mathrm{~s}$ t e i n, The Expansion of Judah in II Chronicles: Territorial's Legitimation for the Hasmoneans? Zeitschrift für Alttestamentliche Wissenschaft 127/2015, s. 669-695.

60 E. U s u e, Theological Perspectives on the Concept of "Yahwe's People" in Ezra and Nehemiah during the Early Post-Exilic Period (539-350 BC), cz. I, Old Testament Essays 18/2005, s. 826-846; cz. II, tamże, 19/2006, s. 205-215. 
chodach święta Paschy (Ezd 6,19-21), a ci, ,którzy przeszli od ludów obcych krajów do Prawa Bożego" (Ne 10,29), zostali dopuszczeni do udziału w odnowieniu przymierza. ${ }^{61}$ Jednak przeważyło stanowisko ekskluzywistyczne: radykalny nakaz oddalenia cudzoziemskich żon i ich dzieci wskazuje nie tylko na ekskluzywizm religijny, lecz również etniczny. Identyfikacja członków wspólnoty będzie się odbywała przez imię ojca, aczkolwiek do istoty politycznej reformy Ezdrasza i Nehemiasza należał także nacisk na rolę kobiety - żony i matki. ${ }^{62}$ Wewnątrzjudejskie dyskusje, których ślady zostały rozpoznane również w Księdze Powtórzonego Prawa ${ }^{63}$, koncentrując się wokół sprawy tożsamości Izraela i zakresu terytorialnego „ziemi Izraela”, trwały do III w. przed Chr., kiedy to rozstrzygnięto je na korzyść koncepcji „małojudejskiej” .

Religia Izraela została poddana gruntownej transformacji, w wyniku czego „filozofia historii” wyrażona przez Kronikarza, mając charakter teologiczny i dydaktyczny, przedstawia tożsamość żydowską i judaizm jako jedyną prawomocną kontynuację wspólnoty sprzed wygnania babilońskiego. Na gruncie tamtej wiary i pobożności, z wieloma przejawami uniwersalizmu - zwłaszcza w nauczaniu proroków - otwierającego się na innych, czyli pogan przyjmujących wiarę w Boga, kształtuje się i umacnia status religii plemiennej, ograniczonej do „czystych”, to jest złączonych więziami krwi, członków plemienia Judy i Beniamina i to nie wszystkich, lecz tylko repatriantów. Zapewne ta zmiana miała korzenie na wygnaniu, gdzie przetrwanie deportowanych Judejczyków zależało od unikania bliskich kontaktów z pogańskim otoczeniem. Lecz nie mniej brzemienne w skutki okazało się unikanie bliskich kontaktów z potomkami pobratymców deportowanych niegdyś z terytorium królestwa Izraela.

${ }^{61}$ P. H. W. L a u, Gentile Incorporation into Israel in Ezra-Nehemiah? Biblica 90/2009, s. 356-373.

62 P. Goodnick, Ezra Rejects Patrilinear Descent, The Jewish Bible Quarterly 26/1998, s. 250-254.

63 G. S z a m o c k i, Wielkoizraelska perspektywa tożsamości Judy w Pwt 11,29-30, Studia Gdańskie 41/2017, s. 17-23. 
Jedno i drugie przyczyniło się do utrwalenia postawy, która doszła do głosu w odmowie przyjęcia współpracy przy odbudowie świątyni, a potem całkowitej separacji od wszystkich, którzy nie byli etnicznymi Żydami. Konfrontacja, o której mowa w Ezd 4,1-5, dała początek istnieniu trwającej do dzisiaj wspólnoty Samarytan. ${ }^{64}$ Obserwuje się znamienną prawidłowość: istnieje zasadniczy kontrast między sytuacją religijną w obu częściach Palestyny w VIII/VII a w V/IV w. przed Chr., bo zarówno w Judzie, jak i na północy zniknęły małe sanktuaria i nie znaleziono żadnych figurek kultowych datowanych na okres perski. ${ }^{65}$ Kult na górze Garizim stał się przedmiotem dosadnego potępiania, z naciskiem na prawomocność kultu i kapłaństwo jerozolimskie. ${ }^{66}$ Nacisk na powrót z wygnania i samodzielną odbudowę świątyni służy podkreśleniu, że to Judejczycy, a nie Samarytanie (ani inni) są prawowitymi kontynuatorami i spadkobiercami Izraela sprzed wygnania babilońskiego. Gôla w Judei, to jest członkowie plemienia Judy i Beniamina oraz lewici, jest przedstawiana jako integralnie związana z Jahwe, stanowiąc jedyną właściwą kontynuację ludu Bożego wybrania. ${ }^{67}$

Dociekając genezy i natury Samarytan trzeba brać poważnie pod uwagę to, że była to niezależna odmiana jahwizmu, stanowiąca

64 Z. R o n, The First Confrontation with the Samaritans (Ezra 4), The Jewish Bible Quarterly 43/2015, s. 117-121.

65 E. S t e r n, The Religious Revolution in Persian-Period Judah, w: O. L i p $\mathrm{s} \mathrm{ch}$ its, J. B le n k in s o p p (red.), Judah and Judeans in the Neo-Babylonian Period, s. 199-205; t e n ż e, Religion in Palestine in the Assyrian and Persian Periods, w: B. B e c k i n g, M.C.A. K o r p e 1 (red.), The Crisis of Israelite Religion. Transformation of Religious Tradition in Exilic and Post-Exilic Times, s. 9-44 (sytuacja w VIIII/VII w. - s. 245-253; sytuacja w V-IV w. - s. 153-255); D. E d e 1 m a n, Cultic Sites and Complexes Beyond the Jerusalem Temple, w: F. S t a u r a k o p o u $1 \mathrm{o} \mathrm{u}$, J. B a r to n (red.), Religious Diversity in Ancient Israel and Judah, New York-London 2010, s. 82-103.

${ }^{66} \mathrm{Ch} . \mathrm{N}$ i h a n, Cult Centralization and the Torah Traditions in Chronicles, w: P. D u b o v s k y, D. M a r k 1, L.-P. S o n n e t (red.), The Fall of Jerusalem and the Rise of the Torah, Tübingen 2016, s. 253-288.

67 S. G r ä t z, Bund und Erwählung in Esra-Nehemiah, w: N. M a c D o n a $1 \mathrm{~d}$ (red.), Covenant and Election in Exilic and Post-Exilic Judaism, s. 128-138. 
kontynuację religii dominującej w królestwie Izraela. ${ }^{68}$ Wskazują na to wszystkie aspekty praktyk religijnych, z jednym wyjątkiem sprawowania kultu na górze Garizim. Świadectwa archeologiczne świadczą, że początki tamtejszego „domu Pana” sięgają połowy V w. przed Chr., ${ }^{69}$ kiedy stało się jasne, że mieszkańcy części północnej zostali definitywnie odsunięci od kultu w sanktuarium jerozolimskim. ${ }^{70}$ Podwaliny już istniały: odrzucenie oferty współpracy z przybyszami z północy sprawiło, że wcześniejsze napięcia przerodziły się w trwały konflikt między Żydami a Samarytanami. ${ }^{71}$ Tekst Ezd 4,1-5 ma wyraźnie wydźwięk antysamarytański. ${ }^{72} \mathrm{~W}$ okresie, gdy powstawała Księga Ezdrasza, po panowaniu Artakserksesa naznaczonym sprzeciwem Samarytan wobec odbudowy murów Jerozolimy $(4,10)$, zyskali oni i utrwalili własną tożsamość. Wrogość Judejczyków wobec nich była już posunięta tak daleko, że to im przypisano przywództwo w spiskowaniu przeciw odbudowie świątyni. W kierunku ekskluzywistycznym poszła też reinterpretacja Pentateuchu, ${ }^{73}$ przede

${ }^{68}$ R. P u m m e r, Samaritanism - A Jewish Sect or an Independent Form of Yahwism? w: M. M o r, F. V. R e it e r e r (red.), Samaritans. Past and Present, Studia Samaritana 5, Berlin-New York 2010, s. 1-24.

${ }^{69}$ Y. Mage n, The Dating of the First Phase of the Samaritan Temple on Mount Gerizim in Light of the Archaeological Evidence, w: O. L i p s c h it s, G. N. K n o p p e r s, R. A 1 b e r $\mathrm{z}$ ( (red.), Judah and Judaeans in the Fourth Century B.C.E., Winona Lake (IN) 2007, s. 157-211; J. D u š e k, Mt Gerizim Sanctuary, Its History and Enigma of Origin, Hebrew Bible and Ancient Israel 3/2014, s. 111-133.

70 J. Warzecha, zanim opublikowano najnowsze ustalenia, datował zbudowanie sanktuarium na górze Garizim na początku IV w. przed Chr; zob. J. W a r z e c h a, Samarytanie-perspektywa polityczna i religijna, w: W. C h r o s t o w s k i (red.), „Stowo Twoje jest prawdą. Księga Pamiątkowa dla Księdza Profesora Stanisława Mędali CMw 65. rocznice urodzin, Ad Multos Annos 3, Warszawa 2000, s. 341.

71 Por. A. D. C r ow n, Redating the Schism Between the Judaeans and the Samaritans, Jewish Quarterly Review 82(1991)1-2, s. 17-50.

72 G. B e t t e n z ol i, Księga Ezdrasza i Księga Nehemiasza, w: W. R. F a rm e r (red. nauk.), W. C h r o s t ow s k i (red. nauk, wyd. pol.), Międzynarodowy komentarz do Pisma Świętego. Komentarz katolicki i ekumeniczny na XXI wiek, Warszawa 2001, s. 577.

73 E. Usue, The Place of Non-Jews/Foreigners in the Early Post-exilic Jewish Community in Ezra-Nehemiah, Old Testament Essay 17/2004, s. 294-314. 
wszystkim w zawężeniu rozumienia przymierza zawartego z Abrahamem i Mojżeszem. Spoiwem religijnego życia żydowskiego po wygnaniu babilońskim, we wszystkich dużych skupiskach - Judea, Babilonia, Egipt - był nacisk na rodzinę i odrzucenie asymilacji. ${ }^{74}$ Obustronna rywalizacja dotyczyła też prawowitej linii kapłańskiej. Niezwykle silny nacisk na rodowody i rolę kapłanów w kronikarskim dziele historycznym sugeruje, że organizacja kultu i personelu świątynnego też przeszła gruntowną transformację, która wymagała uwiarygodnienia. ${ }^{75}$

W sytuacji zagłady Jerozolimy i świątyni, a później jej odbudowy i wznowienia kultu, wyłaniały się zręby judaizmu. Był to jeden z najbardziej przełomowych momentów w historii biblijnego Izraela. ${ }^{76}$ Wykorzystując tradycje przedwygnaniowego Izraela, poddano je adaptacji i aktualizacji, które przynosiły odpowiedzi na klęskę i stanowiły inspirację w ułożeniu życia wspólnoty po zakończeniu wygnania. Gdy kapłan Ezdrasz rozpoczął radykalną działalność reformatorską, stawiając czynnik etniczny wyżej niż wyznawanie tej samej wiary, Tora spisana była gotowa i z niej czerpano argumenty do uzasadnienia przyjętego podejścia. Charakterystyczny dla nowego etapu jest nowy rodzaj przywództwa, którego autorytet zasadza się na objaśnianiu Tory. ${ }^{77}$ Ofiarami gruntownej reformy byli nie tylko ci,

74 R. A 1 b e r t z, Die social- und religionsgeschichtliche Folgen der Exilszeit, Bibel und Kirche 55/2000, s. 127-131.

75 P. S a c c h i, Storia del Secondo Tempio. Israele tra VI secolo a. C e I secolo d. C., Torino 1994, s. 89-104; A. H u n t, Missing Priests. The Zadokites in Tradition and History, Library of Hebrew Bible/Old Testament Studies 452, New York 2006.

76 M. Broshi zalicza go do ośmiu kluczowych wydarzeń w okresie od $734 \mathrm{r}$. przed Chr. do 135 r. po Chr.: 1. zagłada królestwa Izraela; 2. panowanie Ezechiasza; 3. panowanie Sedecjasza; 4. reformy Ezdrasza i Nehemiasza; 5. powstanie hasmonejskie; 6. pierwsze powstanie przeciw Rzymianom; 7. bunty żydowskie za panowania Trajana, 8. powstanie pod wodzą Bar Kochby, przyznając pierwszeństwo reformom Ezdrasza i Nehemiasza oraz powstaniu hasmonejskiemu; M. B ros hi, Eight Critical Junctures in Ancient Jewish History, w: K. D. D o b o s, M. K ö s z e g h y (red.), With Wisdom as a Robe. Qumran and Other Jewish Studies in Honor of Ida Fröhlich, Hebrew Bible Monographs 21, Sheffield 2009, s. 15-22.

77 Z. R o n, Ezra, The First Rabbi, The Jewish Bible Quarterly 44/2016, s. 37-44. 
którzy etnicznie nie stanowili części Izraela, lecz również Judejczycy, którzy zawarli małżeństwa mieszane, oraz Izraelici jako potomkowie plemion północnych odsuniętych od jedności z Jerozolimą. ${ }^{78}$

$\mathrm{Na}$ koniec warto ponowić pytania z zakresu tzw. historii wirtualnej: ${ }^{79}$ Jak wyglądałaby historia i religia Izraela, gdyby starszyzna jerozolimska odpowiedziała pozytywnie na prośbę przedstawioną przez przybyszów z północy i lokalną ludność? Czy odbudowa świątyni odłożyłaby się, jak to się stało, w czasie? - Zapewne nie. Czy świątynia jerozolimska stałaby się zwornikiem całego Izraela, nie ograniczonego jedynie do plemienia Judy i Beniamina? - Zapewne tak. Czy przychylność okazana przybyszom znalazłaby przedłużenie w uniwersalizmie, zdecydowanie bardziej otwartym na spotkanie z poganami zainteresowanymi religią Izraela? - Na pewno tak. Czy w takich warunkach doszłoby do reform przeprowadzonych w połowie V w. przed Chr., skutkujących krzywdą oddalonych kobiet i dzieci? - Zapewne nie. Czy spotkanie wiary w jedynego Boga ze światem nie żydowskim musiałoby czekać aż do pojawienia się Septuaginty jako Biblii Greckiej, najpierw entuzjastycznie przyjętej, a gdy stała się Biblią Kościoła apostolskiego, definitywnie przez rabinów odrzuconej? Zapewne owocne spotkanie świata żydowskiego z nie-żydowskim nastąpiłoby na długo przed zaistnieniem Septuaginty, a odbyłoby się to w środowisku jerozolimskim, nie zaś aleksandryjskim. Pod koniec ery przedchrześcijańskiej, dzięki Biblii Greckiej, na progu judaizmu stały tysiące prozelitów i „bojących się Boga”. Czyż nie pojawiliby się w Jerozolimie znacznie wcześniej i w dużo większej liczbie, gdyby nie odmowa włączenia ich przedstawicieli do odbudowy świątyni? Chociaż nie znamy odpowiedzi na te pytania,

78 "Ezra insisted that the Israelites divorce the wives they had taken from the «peoples of the land». Now, as a matter of fact, the peoples of the land were none other than descendants of those Israelites who had not gone off into exile in Babylonia. They had remained behind, and had not undergone the paradigmatic experience of exile and return. Israel was comprised, in the priests' version, only by those who had gone into exile"; J. N e u s n e r, Transformations in Ancient Judaism. Textual Evidence for Creative Responses to Crisis, Peabody (MA) 2004, s. 21-22.

79 W. C h r o s t o w s k i, Konflikt wokół odbudowy świątyni, s. 82-83. 
warto się zastanowić, co sugeruje również M. Broshi ${ }^{80}$ jak potoczyłaby się historia Izraela, gdyby lakonicznie opisane w Ezd 4,1-5 wydarzenia potoczyły się zupełnie inaczej.

\section{ks. Waldemar CHROSTOWSKI}

Słowa kluczowe: Księgi Kronik oraz Ezdrasza i Nehemiasza, świątynia jerozolimska; wygnanie babilońskie; okres perski; Samarytanie

Keywords: Chronicles and the Books of Ezra and Nehemiah, The Jerusalem Temple; Babylonian exile; Persian period; Samaritans

\section{The Books of Chronicles and Ezra-Nehemiah as a Project of a New Future of Israel Summary}

Chronicles and Ezra-Nehemiah express a different approach to the future of Israel to that given in the Former Prophets. First, the nature and the dating of this part of the Hebrew Bible are discussed, suggesting the end of the $5^{\text {th }}$ and the very beginning of the $4^{\text {th }}$ century B.C. as the time of its origins. Then the retrospection of the past in the two Books of Chronicles is presented, with its very specific attitude towards the Exile. The article focuses its attention on the detailed analysis of Ezra 4,1-5, that represents the very core of this book. Having in mind the identity of the delegation coming to Jerusalem as seen by the author of Ezra and the completely different self-presentation of the delegates from the north, the serious conflict that ensues is described, this bearing analogies with the former antagonisms and tensions between the Kingdom of Judah and the Kingdom of Israel. On the basis of this conflict a new reality emerges, namely Judaism. The religion of the pre-exilic Israel was deeply transformed, limiting itself only to those Judeans who came back from the Exile. As a result of this separation, the question of the "true Israel" started to be more crucial, giving new direction to the project of the national and religious identity of biblical Israel.

${ }^{80}$ M. B r o s h i, Eight Critical Junctures in Ancient Jewish History, w: K. D. D o b o s, M. Kö s z e g hy (red.), With Wisdom as a Robe, s. 21-22. 


\section{Bibliografia}

A c k r o y d P. R, The Chronicler in His Age, JSOTSuppl. 101, Sheffield 1991. A $1 \mathrm{~b}$ e $\mathrm{r} \mathrm{z}$ R., A History of Israelite Religion in the Old Testament Period, t. 1: From the Exile to the Maccabees, London 1994.

A 1 b e r t z R., Die social- und religionsgeschichtliche Folgen der Exilszeit, Bibel und Kirche 55/2000, s. 127-131.

B e c k ing B., Ezra's Re-enactment of the Exile, w: G r a b b e L. L., Leading Captivity Captive. "The Exile" as History and Ideology, JSOTSuppl. 278, European Seminar in Historical Methodology 2, Sheffield 1998, s. 40-61.

B e c k i n g B., Does Ezra Present the Return from Exile as a Second Exodus? Biblische Notizen 177/2018, s. 65-73.

B e d ford P. R., Diaspora: Homeland Relations in Ezra-Nehemiah, Vetus Testamentum 52/2002, s. 147-165.

$\mathrm{B}$ e $\mathrm{n} \mathrm{Z} v \mathrm{i}$ E., Towards a Sense of Balance: Remembering the Catastrophe of Monarchic Judah/(Ideological) Israel and Exile through Reading Chronicles in Late Yehud; w: Ev a n s P. S., W i 11 i a m s T. F. (red.), Chronicling the Chronicler: The Book of Chronicles and Early Second Temple Historiography, Winona Lake, IN 2013, s. 247-265

$\mathrm{B}$ e $\mathrm{n} \mathrm{Z}_{\mathrm{v}}$ i E., Chronicles and Samuel-Kings: Two Interacting Aspects of a Memory System in the Late Persian/Early Hellenistic Period, w: B e ck e r U., B e z z e 1 H. (red.), Rereading the "relecture"? The Question of (Post)chronistic Influences in the Latest Redactions of the Book of Samuel, Tübingen 2014, s. 41-56.

B e $t$ t e $n$ z ol i G., Księga Ezdrasza i Ksiega Nehemiasza, w: Fa r m e r W. R. (red. nauk.), C h r o s t ow s k i W. (red. nauk, wyd. pol.), Międzynarodowy komentarz do Pisma Świętego. Komentarz katolicki i ekumeniczny na XXI wiek, Warszawa 2001, s. 577.

B o d n e r K., Reading the Lists: Several Recent Studies of the Chronicles Genealogies, w: E v a n s P. S., W i 11 i a m s T. F. (red.), Chronicling the Chronicler: The Book of Chronicles and Early Second Temple Historiography, Winona Lake (IN) 2013, s. 29-41.

B rosh i M., Eight Critical Junctures in Ancient Jewish History, w: D o b o s K. D., Kö s ze g hy M. (red.), With Wisdom as a Robe. Qumran and Other Jewish Studies in Honor of Ida Fröhlich, Hebrew Bible Monographs 21, Sheffield 2009, s. 15-22.

$\mathrm{C}$ a r t e r Ch. E., Ideology and Archaeology in the Neo-Babylonian Period. Excavating Text and Tell, w: L i p s c h it s O., O e m in g M. (red.), Judah and the Judeans in the Persian Period, Winona Lake (IN) 2006, s. 301-322. 
C h r o s t o w s k i W., Asyryjska diaspora Izraelitów i inne studia, Rozprawy i Studia Biblijne 10, Warszawa 2003, s. 13-125.

C h r o s t o w s k i W., Babilońskie deportacje mieszkańców Jerozolimy i Judy oraz inne studia, Rozprawy i Studia Biblijne 34, Warszawa 2009, s. 13-108.

C h r o s t o w s k i W., Trzecia Światynia w Jerozolimie i inne studia, Rozprawy i Studia Biblijne 44, Warszawa 2012, s. 38-166.

C h r o s t o w s k i W. Konflikt wokół odbudowy światyni (Ezd 4,1-5). Przyczynek do transformacji religii biblijnego Izraela i narodzin judaizmu, Collectanaea Theologica 89(2019) nr 3, s. 43-83.

$\mathrm{C}$ i e c i e ląg J., Zerubbael and His Role in the Creation of Yehud Province, Polish Journal of Biblical Research 10/2011, s. 57-62.

C o g g i n s R. J., The First and Second Books of Chronicles, Cambridge 1976.

C r o w n A. D., Redating the Schism Between the Judaeans and the Samaritans, JQR 82(1991)1-2, s. 17-50.

$\mathrm{D}$ u š e k J., Mt Gerizim Sanctuary, Its History and Enigma of Origin, Hebrew Bible and Ancient Israel 3/2014, s. 111-133.

E d e $1 \mathrm{~m}$ a $\mathrm{n}$ D., Cultic Sites and Complexes Beyond the Jerusalem Temple, w: S t a u rak o p o u lou F., B a r t o n J. (red.), Religious Diversity in Ancient Israel and Judah, New York-London 2010, s. 82-103.

$\mathrm{G}$ a $\mathrm{n}$ e R., The Role of Assyria in the Ancient Near East during the Reign of Manasseh, Andrews University Seminary Studies 35/1997, s. 21-32.

$\mathrm{Gr}$ ä t z S., Bund und Erwählung in Esra-Nehemiah, w: M a c D o n a ld N. (red.), Covenant and Election in Exilic and Post-Exilic Judaism, Tübingen 2015, s. 128-138.

F a r m e r W. R. (red. wyd. oryg.), C h r o s t ow s k i W. (red. wyd. pol.), Międzynarodowy komentarz do Pisma Świętego. Komentarz katolicki i ekumeniczny na XXI wiek, Warszawa 2000.

F a u s t A., Deportations and Demography in Sixth-Century B.C.E. Judah, w: Wright J. L. (red.), Interpreting Exile. Interdisciplinary Studies of Displacement and Deportation in Biblical and Modern Contexts, Atlanta 2011, s. 91-103.

F in k e l s t e in I., The Expansion of Judah in II Chronicles: Territorial's Legitimation for the Hasmoneans? Zeitschrift für Alttestametliche Wissenschaft 127/2015, s. 669-695.

G i f f o n e B.D., According to Which "Law of Moses"? Cult Centralization in Samuel, Kings and Chronicles, Vetus Testamentum 67/2017, s. 432-447.

Goodn ick P., Ezra Rejects Patrilinear Descent, The Jewish Bible Quarterly 26/1998, s. 250-254. 
G r a b b e L.L., Israel's Historical Reality after the Exile, w: B e c k in $\mathrm{g}$ B., K or p e 1 M.C.A. (red.), The Crisis of Israelite Religion. Transformation of Religious Tradition in Exilic and Post-Exilic Times, Old Testament Studies 42, Leiden 1999, s. 9-44.

H o b s o n R., The Memory of Samaria in the Books of Kings, w: E d e $1 \mathrm{~m}$ a $\mathrm{n}$ D. V., B e n Zv i E. (red.), Memory and the City in Ancient Israel, Winona Lake (IN) 2014, s. 219-229.

H o g 1 und K. G., The Chronicler as Historian: A Comparativist Perspective, w: G r a h a m M. P. i in. (red.), The Chronicler as Historian, Sheffield 1997, s. 19-29.

H un t A., Missing Priests. The Zadokites in Tradition and History, Library of Hebrew Bible/Old Testament Studies 452, New York 2006.

I r u d a y a R., Who are the Samaritans? Vidyajyoti 68/2004, s. 576-594.

$\mathrm{J}$ a $\mathrm{p}$ h e $\mathrm{t}$ S., The Historical reliability of Chronicles: The History of the Problem and Its Place in Biblical Research, Journal for the Study of the Old Testament 33/1985, s. 83-107, toż w:J. Ch. E x u m, The Historical Books, The Biblical Seminar 40, Sheffield 1997, s. 258-281.

$\mathrm{K}$ a 1 i m i I., Historia, historiografia a wiarygodność historyczna. Księga Kronik na tle starożytnego piśmiennictwa bliskowschodniego i grecko-rzymskiego, Poznańskie Studia Teologiczne 23/2009, s. 7-25;

K a 1 i m i I., Starożytny historyk izraelski. Studium o Kronikarzu, jego epoce, miejscu działalności i dziele, Kraków 2016.

K n o p p e r s G. N., I Chronicles 1-9, The Anchor Bible 12, New York 2003.

K n o p p e r s G. N., I Chronicles 10-29, The Anchor Bible 12A, New York 2004.

K n o p p e r s G. N., Judah, Levi, David, Solomon, Jerusalem, and the Temple: Election and Covenant in Chronicles, w: M a c D o n a $1 \mathrm{~d}$ N. (red.), Covenant and Election in Exilic and Post-Exilic Judaism, Tübingen 2015, s. 139-168.

K n o p p e r s G. N., Revisiting the Samarian Question in the Persian Period, w: Lip s chits O., O e m ing M. (red.), Judah and Judaeans in the Persian Period, Winona Lake (IN) 2006, s. 265-289.

L a ng k m m e r H., Księgi Ezdrasza-Nehemiasza. Wstęp - przekład z oryginału - komentarz - ekskursy, Pismo Święte Starego Testamentu II/3, Poznań-Warszawa 1971.

L a n g k a m m e r H., Kwestia źródeł w 1 i 2 Księdze Kronik i technika ich opracowania, w: C h r o s to w s k i W. (red.), „Pan moim świattem”. Księga pamiatkowa dla Księdza Profesora Jerzego Chmiela w 65. rocznice urodzin, Ad Multos Annos 4, Warszawa 2000, s. 214-218;

$\mathrm{L}$ a $\mathrm{n} \mathrm{g} \mathrm{k}$ a $\mathrm{m}$ m e r H., Historia teologizowana. Fenomen interpretacji historii w 1-2Krn, Quaestiones Selectae 17(2010) nr 26, s. 87-106. 
$\mathrm{L}$ a u P. H. W., Gentile Incorporation into Israel in Ezra-Nehemiah? Biblica 90/2009, s. 356-373.

L a w s o n Y o u n g e r K., The Deportations of the Israelites, Journal of Biblical Literature 117/1998, s. 201-227.

L y n c h M. J., The Davidic Covenant and Institutional Integration in Chronicles, w: M a c D o n a $1 \mathrm{~d}$ N. (red.), Covenant and Election in Exilic and Post-Exilic Judaism, Tübingen 2015, s. 169-188.

M a g e $\mathrm{n}$ Y, The Dating of the First Phase of the Samaritan Temple on Mount Gerizim in Light of the Archaeological Evidence, w: L i p s c h it s O., K n o p p e r s G. N., A 1 b e r t z R. (red.), Judah and Judaeans in the Fourth Century B.C.E., Winona Lake (IN) 2007, s. 157-211.

M e r i 11 E. H., The Theology of the "Chronicles": What Difference Does It Make? Journal of the Evangelical Theological Society 59/2016, s. 691-700.

M o o r e M.B., K e 11 e B.E., Biblical History and Israel's Past. The Changing Study of the Bible and History, Grand Rapids (MI)-Cambridge (U.K.) 2011, s. 367-388.

M ü n n i c h M., O pokusach uświęcania historii, albo o nadgorliwości biblijnego Kronikarza stów parę, w: B o r k o w s k a U. (red.), Peregrinatio ad veritatem. Studia ofiarowane profesor Aleksandrze Witkowskiej OSU z okazji 40-lecia pracy naukowej, Prace Wydziału Historyczno-Filologicznego 111, Lublin 2004, s. 315-324;

$\mathrm{N}$ a' $\mathrm{m}$ a n N., Population Changes in Palestine Following Assyrian Deportations, Tel Aviv 20/1993 nr 2, s. 104-124.

$\mathrm{N}$ i h a n Ch., Cult Centralization and the Torah Traditions in Chronicles, w: D u b o v s k y P., M a r k 1 D., S o n n e t L.-P. (red.), The Fall of Jerusalem and the Rise of the Torah, Tübingen 2016, s. 253-288.

N o d e t E., A Search for the Origins of Judaism. From Joshua to the Mishnah, Journal for the Study of the Old Testament 248, Sheffield 1997, s. 154-160.

N o r t h R., Ksiega Ezdrasza i Nehemiasza, w: B r o w n R. E., F it zm y er J. A., M u r p-hy R. E. (red. nauk. wyd. oryg.), Chro s to w s ki W. (red. nauk. wyd. pol.), Katolicki komentarz biblijny, Prymasowska Seria Biblijna 17, Warszawa 2001, s. 340-364.

$\mathrm{O} \mathrm{d}$ e d B., The Settlements of the Israelite and Judean Exiles in Mesopotamia in the 8th-6th Centuries BCE, w: G a 1 i 1 G., W e in f e $1 \mathrm{~d}$ M. (red.), Studies in Historical Geography and Biblical Historiography Presented to Zecharia Kallai, Vetus Testamentum Suppl. 81, Leiden et al. 2000, s. 91-103. $\mathrm{P}$ u $\mathrm{m}$ m e r R., Samaritanism - A Jewish Sect or an Independent Form of Yahwism? w: M o r M., R e it e r e r F. V. (red.), Samaritans. Past and Present, Studia Samaritana 5, Berlin-New York 2010, s. 1-24. 
R o n Z., The First Confrontation with the Samaritans (Ezra 4), The Jewish Bible Quarterly 43/2015, s. 117-121.

$\mathrm{S}$ a c c h i P, Storia del Secondo Tempio. Israele tra VI secolo a. C e I secolo d. C., Torino 1994.

$\mathrm{S}$ c h ü t t e W., Wie wurde Juda israelitiesiert? Zeitschschrift für Alttestamentliche Wissenschaft 124/2012, s. 52-72.

$\mathrm{S}$ é r a n d o u r A., Les récits bibliques de la construction du second temple: leurs enjeux, Transeufratene 11/1996, s. 9-32.

Shan k s H. (red.), Chro s to w s k i W., (tłum. i red. wyd. pol.), Starożytny Izrael. Od Abrahama do zburzenia świątyni jerozolimskiej przez Rzymian, Podręczniki Biblijne 1, Warszawa 2018.

$\mathrm{S} \mathrm{m}$ it h-C h r i s t o p h e r, D. L., Reassessing the Historical and Sociological Impact of the Babylonian Exile (597/587-539 BCE), w: S c o t t J.M. (red.), Exile: Old Testament, Jewish and Christian Perspectives, Journal for Study of Judaism Suppl. 56, Leiden 1997, s. 7-32.

$\mathrm{S} \mathrm{c}$ h w e i t z e r S., The Genealogies of 1 Chronicles 1-9: Purposes, Forms, and the Utopian Identity of Israel, w: E v a n s. S., W i 11 i a m s T. F. (red.), Chronicling the Chronicler: The Book of Chronicles and Early Second Temple Historiography, Winona Lake (IN) 2013, s. 9-17.

$\mathrm{S}$ t e r $\mathrm{n}$ E., The Religious Revolution in Persian-PeriodJudah, w: L i p s c h it s O., B le n k i n s o p p J. (red.), Judah and Judeans in the Neo-Babylonian Period, Winona Lake (IN) 2006, s. 199-205.

$\mathrm{S}$ t e r $\mathrm{n}$ E., Religion in Palestine in the Assyrian and Persian Periods, w: B e c k in g B., K o r p e 1 M.C.A. (red.), The Crisis of Israelite Religion. Transformation of Religious Tradition in Exilic and Post-Exilic Times, Old Testament Studies 42, Leiden 1999, s. 9--44, 153-255.

$\mathrm{S}$ z a m o c k i G., Wielkoizraelska pertspektywa tożsamości Judy w Pwt 11,29-30, Studia Gdańskie 41/2017, s. 17-23.

$\mathrm{T}$ i ñ o J., An Elaboration of Some Theological Issues of Second Temple Judaism in Chronicles and Jubilees, Communio Viatorum 59/2017, s. 25-47.

U s u e E., Theological Perspectives on the Concept of "Yahwe's People" in Ezra and Nehemiah during the Early Post-Exilic Period (539-350 BC), cz. I, Old Testament Essays 18/2005, s. 826-846.

U s u e E., Theological Perspectives on the Concept of "Yahwe's People" in Ezra and Nehemiah during the Early Post-Exilic Period (539-350 BC), cz. II, Old Testament Essays 19/2006, s. 205-215.

U s u e E., The Place of Non-Jews/Foreigners in the Early Post-exilic Jewish Community in Ezra-Nehemiah, Old Testament Essay 17/2004, s. 294-314. 
V a n G e m e r e n W. A. (red. nacz.), The New International Dictionary of Old Testament Theology and Exegesis, t. 1, Carlisle 1996.

$\mathrm{V}$ i e z e 1 E., The Order of the Tribes in 1Chron 2-8 according to the Commentary on Chronicles Attributed to Sa'adia Gaon'as Student, Biblische Notizien 174/2017, s. 91--105.

Walt on J. H., Mat thew s V. H., Chaval a s M. W., Komentarz historyczno-kulturowy do Biblii Hebrajskiej, Prymasowska Seria Biblijna 24, Warszawa 2005.

W a r z e c h a J., Samarytanie-perspektywa polityczna i religijna, w: C h r o s t o w s k i W. (red.), ,,Stowo Twoje jest prawda”. Księga Pamiatkowa dla Księdza Profesora Stanistawa Mędali CM w 65. rocznicę urodzin, Ad Multos Annos 3, Warszawa 2000, s. 332-343.

$\mathrm{W}$ e $11 \mathrm{~h}$ a u s e n J., Prolegomena zur Geschichte Israels, Berlin $1883^{2}$.

W i 11 i T., The Chronik als Auslegung, FRLANT 106, Göttingen 1972.

Ya ma u ch i E., The Eastern Jewish Diaspora under the Babylonians, w: Chavalas M. W., Law son Younger K. jr. (red.), Mesopotamia and the Bible. Comparative Explorations, Grand Rapids (MI) 2002, s. 356-377.

$\mathrm{Z}$ a d o k R., Judeans in Babylonia - Updating the Dossier, w: G a r b a y U., S e c u nd a Sh. (red.), Encounters by the Rivers of Babylon. Scholarly Conversations Between Jews, Iranians and Babylonians in Antiquity, Texts and Studies in Ancient Judaism 160, Tübingen 2014, s. 109-129.

$\mathrm{Z}$ e $\mathrm{t}$ a 1 A., The Province of Samaria (Assyrian "Samerina") in the Late Iron Age (Iron Age III), w: L i p s c h it s O., O e m i n g M. (red.), Judah and the Judeans in the Persian Period, Winona Lake (IN) 2006, s. 377-412.

Z u n z L., Dibre hajamim oder die Bücher der Chronik, w: t e n ż e, Die Gottesdienstlichen Vorträge der Juden historisch entwickelt, Frankfurt 1832. 